モンテカルロ・シミュレーションを用いた動的ポートフォリオ最適化モデル

$\begin{array}{cc}\text { 高屋 } \text { 圭介 }^{1} & \text { 枇々木 規雄 } \\ \text { 大和証券株式会社 } & \text { 慶應義䜃大学 }\end{array}$

(受理 2011 年 8 月 7 日; 再受理 2012 年 6 月 4 日; 電子版公開 2012 年 7 月 24 日)

和文概要 多期間ポートフォリオ最適化問題を確率計画モデルとして記述すると, 投資比率や売買回転率の 制的を入れることができるなど，実用的なモデル化を行うことができる．枇々木 [11] はシミュレーションパス を用いて収益率などの分布を柔軟に記述して多期間最適化を行うモデルして，混合型最適化モデルを提案し ている. しかし，混合型最適化モデルはパスごとに異なる意思決定 (条件付き意思決定) を蕨密に行うには大 量の意思決定ノードを必要とする．それに対し，本研究では混合型最適化モデルをベースに投資量関数を工夫 して，状態に依存した最適な意思決定が可能な線形近似モデルを提案し，その有用性を検証する．既存の確率 計画モデル (シミュレーション型モデル，混合型モテル) に加えて，多期間ポートフォリオ最適化問題に対す る異なるアプローチ (解析解, モンテカルロ回㷌)も含めて, 此較分析を行う。数值分析では, CRRA 型効用 最大化問題および一次の下方部分積率最小化問題の而方において，線形近似モデルは他のモデルに比べて目的 関数が改善し，初期時点の投資比率も解析解に近づいた。 また，混合型最適化モデルに比べて，同規模の問題 設定でも目的関数の値が改善した. さらに, CRRA 型効用最大化問題では Brandt et al. [4]の提案したモンテ カルロ回㷌による数值解法に比べ, 期待効用の増大だけでなく, 状態に応じた最適な意思決定が解析解に近づ き，多期間ポートフォリオ最適化問題の解として望ましい性質を渶たすことを確認できた。

キーワード: 金融, 多期間ポートフォリオ最適化, 数理計画, シミュレーション

\title{
1.はじめに
}

ポートフォリオ最適化問題は, 多くの場合, 一期間最適化モデルを利用する。期間モデル は投資比率に制約を入れるなどの操作や，モンテカルロ・シミュレーションを利用してシナ リオを生成する場合でも容易に解くことができるなど，実用上望ましい性質を満たしてい る. 一方，多期間ポートフォリオ最適化モデルは，期中のリバランスを考慮に入れることが できるなど，年金基金や保険の ALM，家計のフィナンシャル・プランニングなどの現実の 資産運用問題に適用することができる。しかし，一般に多期間ポートフォリオ最適化問題の 解析解を求めることは難しく，CRRA 型効用関数を最大化する Kim and Omberg [16] や一 次の下方部分積率 (リスク尺度) を最小化する Cvitanić and Karatzas [7] など, 連続時間モ デルにおけるいくつかの特殊なケースに限られている. 解析解が求められない場合には偏微 分方程式の数値解法を利用して近似解を得ることはできる. 数值解を求める研究も盛んに行 われており，他にもモンテカルロ法(シミュレーション法) と確率計画モデルによる方法の 2 種類がある. Detemple, Garcia and Rindisbacher [8] はモンテカルロ法として, (1) モンテ カルロ・マリアバン微分 (MCMD), (2) モンテカルロ共変動 (MCC), (3) モンテカルロ回 㷌 (MCR), (4) モンテカルロ有限差分 (MCFD) の 4 種類の方法を紹介するとともに数值分 析により比較している。これらのモデルは複雑な確率分布の記述は可能であるが, 連続時間

\footnotetext{
1本稿の内容は慶應義塾大学大学院理工学研究科に所属していたときに行われた研究成果であり, 大和証券株 式会社としての見解をいかなる意味でも表さない.
} 
モデルと同様に投資比率に制約を入れるなどの処理は困難なことが多い.そのため，実際の 問題において考慮すべきリバランスの時期 (離散時間での取り扱い) や空売り禁止制約など を含めると解を求めることができないという問題点がある。一方, 確率計画モデルは制約も 含めて, 柔軟に現実の問題を記述することが可能で, 線形計画問題であれば洗練されたソフ トウェアを用いて大規模な最適化問題を解くこともでき，最適解を導出することができる. 確率計画モデルには定番モデルであるシナリオ・ツリー型モデルと枇々木 $[10]$ によるシミュ レーション型モデル，枇々木 $[11]$ による混合型モデルがある.シナリオ・ツリー型モデルは 収益率分布をシナリオ・ツリーで表現するため, 複雑な分布を厳密に記述しようとすると, 問題規模が指数的に増加するという問題点が生じる.一方, シミュレーション型モデルと混 合型モデルは大量のサンプルパスを利用することでモンテカルロ法と同様に複雑な分布も 記述可能である. Hibiki[14] はこれらのモデルを比較し, 混合型モデルがシナリオ・ツリー 型モデルに比べてリスクを適切に評価し，管理できることを示している．混合型モデルは柔 軟なモデル記述が可能であるが, 状態の集合に対して同一の意思決定をするため，パスごと に異なる意思決定 (条件付き意思決定) を厳密に行うことができない。そこで，本研究では 枇々木 [11], Hibiki [14](以降, 枇々木 $[11,14]$ ) の混合型モデルにおいて, 解析解の特徽を考 慮して, 投資量関数における同一ノード内の投資の意思決定を表す決定変数を状態変数 (各 状態での保有資産量やリスク資産の期待リターンの情報)の関数にすることで, 状態に依存 した意思決定を可能なモデルを提案する。このモデルを線形近似モデルと呼ぶ. 確率計画モ デルの定式化として解析解の特徽を織り込んで構築した融合モデルの提案は先行研究には ない特徴である ${ }^{2}$. 線形近似モデルの有用性を検証するために従来のアプローチと比較を行 うが, この比較分析も本研究の特徵である. 多期間ポートフォリオ最適化問題に対する異な るアプローチを比較した研究として, 梅内 [17] はモンテカルロ回㷌の数値解の精度を上げ る方法を提案するとともに, Kim and Omberg[16] の解析解と比較した研究を行っている. また, Kawaguchi and Hibiki [15] は一次の下方部分積率 (以降は LPM(1) と呼ぶ) に対する Cvitanić and Karatzas [7] の解析解と混合型モデルによる数值解を比較し，その近似精度を 評価している. しかし, 解析解, モンテカルロ法, 確率計画モデルという大きく異なる 3 種 類のアプローチを比較した論文は著者たちの知る限り存在しない. 本研究では, CRRA 型 効用関数に対する Kim and Omberg[16], LPM(1) に対する Cvitanić and Karatzas [7] で示 されている連続時間解析解や, Brandt et al. [4] で提案されたモンテカルロ回帰による数値 解法と比較することで，モデルの性質を調べる。

ところで, 解析解およびモンテカルロ回㷌にはない確率計画モデルの特徴は, 容易に資産 数を増やしたり，制約を入れることが可能なことである．しかし，本研究においては比較可 能性を確保するために，リスク資産を $1 つ ，$ 制約条件なしで比較をしている．したがって， 確率計画モデルの特徴を生かすことができず, 確率計画モデルにとっては不利な比較方法で あることをあらかじめ記しておく．したがって，本研究で提案する線形近似モデルがその他 の計算法に比べて遜色のない結果が得られれば，柔軟性を持つモデルの有用性を示せたと

\footnotetext{
${ }^{2}$ Calafiore [5] は多期間平均・分散モデルの枠組みで，投資額が収益率のアフィン関数に従う数理計画モデルを 提案している。 しかし，単にロバスト最適化の調整変数のアイデアを利用しただけで, 解析解の特徽を取り入 れるという考え方ではない. 枇々木 [13]も投資量関数の例として順張り戦略と逆張り戦略を表す投資量関数や 時系列相関を考慮した投資量関数を用いたモデルの定式化を示している.最適解を 1 期前の収益率の線形関数 として表現する定式化の方法であるが，これも投資戦略を導入するという考え方である. 本稿では投資量関数 の設定を, 解析解をべースに線形式として記述しているが, これは数值計算において解析解の特徵を考㦄して モテルを評価したととらえることもできる。
} 
言ってもよいだろう.

先行研究にはない本研究の貢献をまとめると, 大きく以下の 3 点となる.

(1) 解析解の特徽を考慮して投資量関数を定義し, 確率計画問題として定式化を行っている. 解析解の特徽を柔軟な確率計画モデルの定式化の中で生かすことができる.

(2) CRRA 型効用関数を用いて, 解析解, モンテカルロ法, 確率計画モデルという異なる 3 種類のアプローチに対する最適解を比較し，考察した論文は他には存在しない. 具体的 には, Kim and Omberg[16]の連続時間モデルの解析解, Brandt et al. [4] のモンテカル 口回帰, 枇々木 $[11,14]$ の混合型モデル, 線形近似モデルの数值解を比較する.

(3) Cvitanić and Karatzas [7] の連続時間モデルの解析解が得られている LPM(1)に対して, 解析解と混合型モデル，線形近似モデルによる数值解を比較する.

本論文の構成は以下の通りである. 2 節では比較对象の解析解, 数值解法の概要について述 ベる. 3 節では提案するモデルの定式化とその理論的解釈を述べる．4節では数值分析を用 いて CRRA 型効用でのモデルの性質を比較する．5節では LPM(1) 最小化問題に対して，同 様に数値分析を行い議論する. 6 節ではまとめと今後の課題を述べる.

\section{2. 比較対象とする先行研究}

数值分析において比較対象とするモデルの前提, 定式化およびその解について示す. 表 1 に 比較対象とするモデルを示す．表 1 の記載事項は，モデル提案者であり，括弧内には本稿に おける記載節 (項)を示している.

表 1: 比較対象

\begin{tabular}{c|c|c}
\hline モデル & CRRA 型期待効用最大化 & LPM(1) 最小化 \\
\hline \hline 解析解 (連続時間) & Kim and Omberg [16] (2.1.1) & Cvitanić and Karatzas [7] (2.1.2) \\
\hline モンテカルロ回帰 & Brandt et al.[4] (2.2.1) & (利用不可能) \\
\hline 混合型最適化モデル & \multicolumn{2}{|c}{ 枇々木 $[11,14](2.2 .2)$} \\
\hline 線形近似モデル & \multicolumn{2}{|c}{ 本研究の提案モデル $(3.1)$} \\
\hline
\end{tabular}

解析解以外は離散時間での解の導出を行うモデルである. 多くの多期間ポートフォリオ問 題の解法は連続時間モデルの近似解法として利用されており ${ }^{3}$, 離散時間モデルの解法では ない. 本研究で提案するモデルの目標は, モンテカルロ・シミュレーションによる状態の詳 細な記述, 状態に対して一対一対応した条件付き意思決定, 離散時間での意思決定, 制約条 件の導入を含めた解を求めることである．そこで, 離散時間モデルであるモンテカルロ回帰 と混合型最適化モデルの二つを比較対象としている。

\section{1. 連続時間の解析解}

\subsubsection{CRRA 型効用}

Kim and Omberg[16] はリスク資産が一つで，その期待リターンが OU 過程に従う設定で 最適ポートフォリオを解析的に導出している. リスク資産価格を $S_{t}$, リスク資産の Price of Risk (POR, 状態価格)を $X_{t}$ とする. $S_{t}$ および $X_{t}$ は確率過程とし, 二次元ウィーナー過程 $\left(w_{1 t}, w_{2 t}\right)$ を想定する.リスク資産の期待リターンを $\mu_{t}$, ボラティリティを $\sigma_{t}, X_{t}$ の無条件 期待值を $\bar{X}, X_{t}$ の平均回帰パラメータを $\lambda_{x}, X_{t}$ のボラティリティを $\sigma_{x}$, 相関係数を $\rho$, 無

3詳しくは, Detemple, Garcia and Rindisbacher [8] を見よ. 
リスク金利を $r$ とすると, リスク資産価格と状態価格のプロセスは式 $(2.1) \sim(2.4)$ の通りに 定義される.

$$
\begin{aligned}
\frac{d S_{t}}{S_{t}} & =\mu_{t} d t+\sigma_{t} d w_{1 t} \\
d X_{t} & =-\lambda_{x}\left(X_{t}-\bar{X}\right) d t+\sigma_{x} d w_{2 t} \\
X_{t} & =\frac{\mu_{t}-r}{\sigma_{t}} \\
E\left[d w_{1 t} d w_{2 t}\right] & =\rho d t
\end{aligned}
$$

効用関数は HARA 型を利用可能だが，本稿ではその特殊なケースである CRRA 型を利用 する.これは, Brandt et al. [4] や梅内 [17], Detemple et al. [8]において比較対象とされて おり，数值計算も容易なためである.リスク回避度を $\gamma$, 佩期時点 $T$ における富を $W_{T}$ とす ると, CRRA 型の効用関数 $U\left(W_{T}\right)$ は式 $(2.5)$ で定義される. 期中の富 $W_{t}$ の確率過程は式 (2.6) で定義される． $\pi_{t}$ はその時点での投資比率とする.

$$
\begin{aligned}
U\left(W_{T}\right) & =\frac{W_{T}^{1-\gamma}}{1-\gamma} \\
d W_{t} & =r\left(1-\pi_{t}\right) W_{t} d t+\frac{d S_{t}}{S_{t}} \pi_{t} W_{t}
\end{aligned}
$$

連続時間における最適ポートフォリオ $\pi\left(X_{t}, \tau\right)$ は式 $(2.7)$ で求められる. 満期 $T$, 残存期 間 $\tau=T-t$ とする. $B_{\tau}, C_{\tau}$ は残存期間 $\tau$ から求まり, 状態変数 $X_{t}$ の值によらず一定であ る.また，CRRA 型であるため，富 $W_{t}$ は投資比率に影響を及ほさない。

$$
\pi\left(X_{t}, \tau=T-t\right)=\frac{X_{t}}{\gamma \sigma_{t}}+\frac{\rho \sigma_{x}\left(B_{\tau}+C_{\tau} X_{t}\right)}{\gamma \sigma_{t}}
$$

本稿では，数值分析の際にリスク資産のボラティリティを一定 $\left(\sigma_{t}=\sigma\right)$ とする ${ }^{4}$. この場 合，最適投資比率は式 $(2.7)$ より $X_{t}$ の一次式となる.

\subsection{2. 一次の下方部分䅡率 $(\operatorname{LPM}(1))$}

Cvitanić and Karatzas [7] はリスク資産が一つの場合において, LPM(1) を最小化した場合 の解析解を示した. 定式化は Kawaguchi and Hibiki [15] と同様にする.リスク資産価格 $S_{t}$ の 確率過程は式 (2.1) と同一であるが, 期待リターンとボラティリティは一定 $\left(\mu_{t}=\mu, \sigma_{t}=\sigma\right)$ とする.つまり, 一次元ウィーナー過程 $w_{t}$ を利用して, リスク資産は式 $(2.8)$ の確率過程に 従うとしている.

$$
\frac{d S_{t}}{S_{t}}=\mu d t+\sigma d w_{t}
$$

目標富を $W_{G}$, 最終時点の富を $W_{T}$ とすると, 不足額の平均を最小化する問題は式 $(2.9)$ となる.ただし， $x^{+}=\max \{x, 0\}$ である.

$$
\min \mathrm{E}\left[\left(W_{G}-W_{T}\right)^{+}\right]
$$

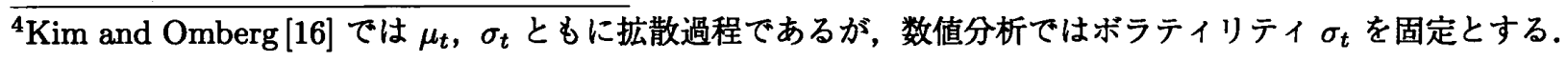


連続時間における最適投資比率 $\pi\left(t, Y_{t}\right)$ は式 $(2.10)$ で与えられる.ここで, $Y_{t}$ は時点 $t$ における積立比率, $\Phi(x)=\frac{1}{\sqrt{2 \pi}} \int_{-\infty}^{x} \exp \left(-\frac{y^{2}}{2}\right) d y$ は標準正規分布の分布関数, $\varphi(x)=$ $\frac{1}{\sqrt{2 \pi}} \exp \left(-\frac{x^{2}}{2}\right)$ は標準正規分布の密度関数を示す.

$$
\begin{aligned}
\pi\left(t, Y_{t}\right) & =\left\{\begin{array}{lr}
\frac{1}{\sigma \sqrt{T-t} Y_{t}} \varphi\left(\Phi^{-1}\left(Y_{t}\right)\right) & \left(0<Y_{t} \leq 1\right) \\
0 & \left(Y_{t}>1\right)
\end{array}\right. \\
Y_{t} & =\frac{W_{t}}{W_{G} \exp (-r(T-t))}
\end{aligned}
$$

最適投資戦略に従って投資をした場合, 時点 $t$ の保有資産 $W_{t}^{*}$ は式 $(2.12)$ で求められる.

$$
\begin{aligned}
W_{t}^{*} & =W_{G} \exp (-r(T-t)) \Phi\left(\frac{D_{t}}{\sqrt{T-t}}\right) \\
\text { ただし, } D_{t} & =\sqrt{T} \Phi^{-1}\left(Y_{0}\right)+\left\{\frac{1}{\sigma} \log \left(\frac{S_{t}}{S_{0}}\right)-\left(\frac{r}{\sigma}-\frac{\sigma}{2}\right) t\right\}
\end{aligned}
$$

最適投資比率 $\pi$ は積立比率 $Y_{t}$ に依存し, 式 $(2.11) \sim(2.13)$ より積立比率 $Y_{t}$ は富 $W_{t}$ に依存 するため，最適投資比率は富 $W_{t}$ に依存する。

\section{2. 数值解法}

\subsection{1. モンテカルロ回帰}

Brandt et al. [4] はベルマン方程式を解く方法として，モンテカルロ法を利用する手法を提 案した.この方法は価値関数をテイラー展開で近似し, 条件付き期待値を最小二乗推定する ことで，モンテカルロ法を利用できる数値解法となっている．離散間隔を $\Delta t$, 時点 $s$ から $s+1$ のリスク資産の超過リターンを $R_{s+1}^{e}$, 無リスク金利で運用した場合のリターンを $R^{f}$, 状態変数を $Z_{t}$ とすると, 時点 $t$ での価值関数 $V_{t}$ は式 $(2.14)$ のようになる ${ }^{5}$.

$$
\begin{aligned}
V_{t}\left(W_{t}, Z_{t}\right) & =\max _{\left\{\pi_{s}\right\}_{s=t}^{T-1}} \mathrm{E}_{t}\left[U\left(W_{T}\right)\right] \\
& =\max _{\pi_{t}} \mathrm{E}_{t}\left[\max _{\left\{\pi_{s}\right\}_{T-1}^{t+1}} \mathrm{E}_{t+1}\left[U\left(W_{T}\right)\right]\right] \\
& =\max _{\pi_{t}} \mathrm{E}_{t}\left[V_{t+1}\left(W_{t}\left(\pi_{t} R_{t+1}^{e}+R^{f}\right), Z_{t+1}\right)\right] \\
\text { s. t. } & W_{s+1}=W_{s}\left(\pi_{s} R_{s+1}^{e}+R^{f}\right)
\end{aligned}
$$

ここで, 式 (2.14) において, 右辺の (期待值の中にある) $V_{t+1}$ を $\pi_{t}$ に関してテイラー展 開し, 投資比率 (決定変数) $\pi_{t}$ と条件付き期待值 (各状態において一意に求まる值) を分離す る. Brandt et al. [4] は $\pi_{t}=0$ における $W_{t+1}$ で, 梅内 [17] は近視眼的ポートフォリオで 運用した場合の $W_{t+1}$ でテイラー展開する方法を示している. Brandt et al. [4] で示された, ${ }^{5} T$ は計画期間を表す. 2 年間のモデルで $\Delta t=0.25$ なら $T=8$ である.この表記は, 混合型モデルでも利用 している. 解析解では $T$ は年数を示している.

${ }^{6}$ 本研究では，近視眼的 (myopic) ポートフォリオと一期間ポートフォリオは別のものとして取り扱う. 前者は 瞬間的な状態価格に対する最適投資比率である. 後者は最終時点までリバランスしない場合の最適投資比率で ある. 多期間離散時間モデルにおいて, 時点 $T-\Delta t に お け る$ 解は, 時点 $T$ までリバランスできないため, 一

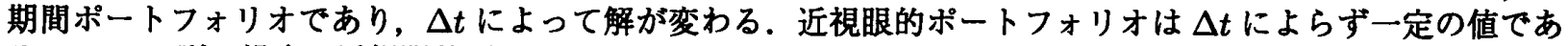
る. CRRA 型の場合, 近視眼的ポートフォリオ (myopic な解) は時点 $T$ における解に該当する. $\Delta t \approx 0$ にお いてはこの二つはほほ同じ值であり，考察ではそれを利用して解の検証を行う。 
$W_{t+1}=W_{t} R^{f}$ 周りで 4 次までテイラー展開する方法を式 (2.17) に示す. 効用関数は式 (2.5) と同じ CRRA 型とする. 確率過程は式 (2.1) (2.4) と同様にする. 無りスク金利は $r$ で一定 なので, $R^{f}=\exp (r \Delta t)$ である．記述を容易にするため， $\Psi_{t}$ を式 (2.16) で定義する. 状態 変数 $Z_{t}$ は, 式 $(2.16)$ を満たすように設定した変数で, 仮に Kim and Omberg [16] と同じ設 定であるなら, 状態価格 $X_{t}$ が該当する7

$$
\max _{\left\{\pi_{s}\right\}_{s=t+1}^{T-1}} \mathrm{E}_{t+1}\left[\left(\prod_{s=t+1}^{T-1}\left(\pi_{s} R_{s+1}^{e}+R^{f}\right)\right)^{1-\gamma}\right]=\Psi_{t+1}\left(Z_{t+1}\right)
$$

価値関数をテイラー展開すると, 式 $(2.17)$ になる. 記述の煩雑さを避けるため, $\Psi_{t+1}\left(Z_{t+1}\right)$ を $\Psi_{t+1}$ と表記する.

$$
\begin{aligned}
& V_{t}\left(W_{t}, Z_{t}\right)=\max _{\pi_{t}} \mathrm{E}_{t}\left[\left(\frac{W_{t+1}^{1-\gamma}}{1-\gamma}\right) \Psi_{t+1}\right] \\
& \approx \max _{\pi_{t}}\left(W_{t} R^{f}\right)^{1-\gamma}\left\{\frac{1}{1-\gamma} \mathrm{E}_{t}\left[\Psi_{t+1}\right]+\frac{1}{R^{f}} \mathrm{E}_{t}\left[R_{t+1}^{e} \Psi_{t+1}\right] \pi_{t}-\frac{\gamma}{2\left(R^{f}\right)^{2}} \mathrm{E}_{t}\left[\left(R_{t+1}^{e}\right)^{2} \Psi_{t+1}\right] \pi_{t}^{2}\right. \\
& \left.\quad+\frac{\gamma(\gamma+1)}{6\left(R^{f}\right)^{3}} \mathrm{E}_{t}\left[\left(R_{t+1}^{e}\right)^{3} \Psi_{t+1}\right] \pi_{t}^{3}-\frac{\gamma(\gamma+1)(\gamma+2)}{24\left(R^{f}\right)^{4}} \mathrm{E}_{t}\left[\left(R_{t+1}^{e}\right)^{4} \Psi_{t+1}\right] \pi_{t}^{4}\right\}
\end{aligned}
$$

式 (2.17) より, パスごとに条件付き期待値 $\mathrm{E}_{t}\left[\left(R_{t+1}^{e}\right)^{n} \Psi_{t+1}\right]$ が求まれば，数值計算で最適 ポートフォリオを導出できる. 時点 $T-1$ からバックワードに計算をすれば, 各時点での期 待値計算が可能となる．境界条件として，すべてのパスで $V_{T}=1$ とする. Brandt et al. [4] では, 時点 $t$, パス $i$ における条件付き期待值 $\mathrm{E}_{t}\left[\left(R_{t+1}^{e}\right)^{n} \Psi_{t+1}\right]$ を, 状態価格 $X_{t}$ の一次式と みなし，クロスセクショナル回帰して推定した値を用いている，具体的には，パス $i$ におけ る時点 $t$ から時点 $t+1$ の超過収益を $R_{t+1}^{e, i}$ として, 式 (2.18) でパラメータ $\beta_{n, 0}, \beta_{n, 1}$ を最小 二乗推定する. そして, 推定したパラメータ $\hat{\beta}_{n, 0}, \hat{\beta}_{n, 1}$ を代入して計算した式 $(2.19)$ の右辺 の值を条件付き期待值として利用する ${ }^{8}$. より一般的には, 状態变数 $Z_{t}$ の多項式や過去の経 路情報を利用することが可能だが，本稿では一次式の場合のみ取り扱う.

$$
\begin{aligned}
\left(R_{t+1}^{e, i}\right)^{n} \Psi_{t+1}^{i} & =\beta_{n, 0}+\beta_{n, 1} X_{t}^{i}+\epsilon^{i},(n=1,2,3,4) \\
E_{t}^{i}\left[\left(R_{t+1}^{e}\right)^{n} \Psi_{t+1}\right] & =\hat{\beta}_{n, 0}+\hat{\beta}_{n, 1} X_{t}^{i},(n=1,2,3,4)
\end{aligned}
$$

紙面の都合上定式化は省略するが, 近視眼的ポートフォリオ周りで展開した場合は梅内 $[17]$ を参照されたい.

\section{モンテカルロ回帰の計算方法}

式 (2.17) は 4 次関数の最大化問題であり, 最適解を求める手法が複数提案されている. 本 研究では表 2 に示した 7 通りの場合に限定して比較を行い, 最も安定した計算方法を採用 する.

表 2 について説明する．4 種類の計算アルゴリズムの比較を行う。期待効用最大化以外の 3 つでは, 式 $(2.17)$ の右辺の 4 次関数を投資比率 $\pi_{t}$ で偏微分し, $\frac{\left.\partial \mathrm{E}_{t} \cdot \cdot\right]}{\partial \pi_{t}}=0$ になる $\pi_{t}$ を最適 7状態変数 $Z_{t}$ だけで最適解を計算することができると仮定している，そのため，具体的な関数は不明なもの の, この形で定式化した.

8各パスで期待值を計算することを明示的に示すために，条件付き期待値に $i$ を付けている. 
表 2: モンテカルロ回帰の計算手法

\begin{tabular}{|c|c|c|c|}
\hline テイラー展開位置 & 初期解 & 計算アルゴリズム & 出典 \\
\hline \multirow{4}{*}{$\begin{array}{c}\text { 無リスク金利 } \\
\text { [MCR0] }\end{array}$} & \multirow{4}{*}{2 次の解 } & BGSS & Brandt et al. [4] \\
\hline & & Newton Raphson & 梅内 [17] \\
\hline & & 期待効用最大 & vBB [2] \\
\hline & & 二乗値最小化 & 本研究で用意 \\
\hline 近視眼的 & \multirow{3}{*}{ 近視眼的解 } & Newton Raphson & 梅内 [17] \\
\hline ポートフォリオ & & 期待効用最大 & $\mathrm{vBB}[2]$ \\
\hline [MCRmyopic] & & 二乗值最小化 & 本研究で用意 \\
\hline
\end{tabular}

投資比率とみなす。 BGSS は当該論文内に記載されたアルゴリズムで計算を行う。 Newton Raphson は梅内 [17] と同様に，偏微分した方程式の解を Newton-Raphson 法を利用して解 く. 二乗值最小化では, $\left(\frac{\partial \mathrm{E}_{t}[\cdot]}{\partial \pi_{t}}\right)^{2}$ を最小化する最適化問題を解く方法であり, 本研究での比 較用に新たに用意する。

期待効用最大は式 (2.17) の右辺の 4 次関数を最大化する最適化問題を解く方法である.こ のアルゴリズムは van Binsbergen and Brandt[2]において，空売り禁止制約がある場合に おける解法として $\pi_{t}$ を 0 から 1 まで 0.01 刻みで動かし，その中で最大の期待効用値をとる $\pi_{t}$ を最適解とみなす方法を，制約がない場合に適用したものである．二乗值最小化と期待 効用最大は統計解析ソフト Rの関数 optim を利用して計算する.

初期解はテイラー展開の位置に対して固定とする. Brandt et al. [4] では初期解として, テ イラー展開を 2 次まで行った場合に偏微分した方程式を解いて求まる解を利用する. 近視眼 的ポートフォリオ周りで展開する場合は初期值として近視眼的ポートフォリオを利用する.

本研究の設定では，二乗値を最小化する方法が計算時間は長いものの ${ }^{9}$, 多くのパラメー 夕設定に対して安定して解を求めることができたため, 以降の数值実験ではこの方法を採用 する ${ }^{10}$. なお, 求解できた場合の值はどの方法でも差はほとんどない.テイラー展開の位置 は無リスク金利，近視眼的ポートフォリオ両方を利用し，それぞれ [MCR0]，[MCRmyopic] と示す。

\subsection{2. 混合型多期間最適化モデル}

枇々木 $[11,14]$ によって提案された混合型多期間最適化モデルを示す. 本研究ではリスク資 産が一つの場合であるため, それに応じた定式化を示す．他のモデルと違い, リスク資産価 格の確率過程や目的関数の種類に限定されない記述となる.なお, 本研究では混合型最適

\footnotetext{
9計算時間は付録 A を参照されたい。

${ }^{10}$ Detemple, Garcia and Rindisbacher [8] によると, BGSSのアルゴリズムは 10000 セットのうち $7229 セ ッ$ 卜でしか成功していない. Newton-Raphson も，著者が行った限りでは非現実的な解を求めることがある. 期 待効用を最大化する方法は係数条件によっては解が発散するため，本研究のように投資比率に制約がない問題 での適用には注意が必要である. 解が非現実的というのは, 例えば最終時点の富がマイナスになる, 投資比率 が他のパスと比べて極端に違う值をとる，などである．特に，最終時点の富がマイナスになり，効用がプラス の值をとる可能性を回避できないのは計算上問題が起こりやすい. 後進演算を用いるモンテカルロ回㷌におい て，非予想条件を満たしつつ富がマイナスになることを回避する定式化は困難である。なお，計算失敗はり フトゥェアの収束の影響ではなく，式 $(2.17)$ における $\pi_{t}$ の 4 次の項の影䇾である. 理論的には $\pi_{t}^{4}$ の係数は 負であり，それによって有限の投資比率が最適解となる。一方, モンテカルロ回㷌では最小二乗推定するため 係数が正になる可能性が存在し, 最適投資比率が発散する。結果, 投資比率が非常に大きくなるパスでリター ンがマイナスになると, 富がマイナスになってしまう.
} 
化モデルとその発展形である線形近似モデルの数值計算を (株) 数理システムの RNUOPT Ver.1で行う．実装においては，枇々木 [12]のコンパクト表現を利用する．また，モデル名 の表記において, 混合型でノード数が1のものをシミュレーション型と表記する.

(1) 集合および添字

$s$ : 決定ノードを表す添字で, 時点 $t$ とともに記述する

$s^{\prime}$ : 任意の決定ノード $s$ につがっている 1 時点前の決定ノードを表す添字

$V_{t}^{s}: t$ 時点の決定ノード $s$ に含まれるパスの集合

$S_{t}: t$ 時点の決定ノード $s$ の集合

(2) パラメータ

$I:$ サンプルパスの本数

$T:$ 最終時点

$\rho_{0}:$ 時点 0 におけるリスク資産の価格

$\rho_{t}^{i}$ : 時点 $t$, パス $i$ におけるリスク資産の価格 $(t=1, \ldots, T ; i=1, \ldots, I)$

$r:$ 無リスク金利

$W_{0}:$ 初期時点の富

$W_{G}: \operatorname{LPM}(1)$ の場合の目標富

$\gamma$ : CRRA 型効用関数のリスク回避度

\section{(3) 決定変数}

$z_{0}: 0$ 時点のリスク資産への投資量

$z_{t}^{s}: t$ 時点のノード $s$ の投資量のベースを表す基礎変数 $\left(t=1, \ldots, T-1 ; s \in S_{t}\right)$

$q^{i}: \operatorname{LPM}(1)$ を計算するための中間変数 $(i=1, \ldots, I)$

\section{(4) その他定義式}

$W_{t}^{i}:$ 時点 $t$, パス $i$ における富 $(t=1, \ldots, T ; i=1, \ldots, I)^{11}$

$U\left(W_{T}^{i}\right)$ : 最終時点 $T$, パス $i$ 富における効用 $(i=1, \ldots, I)$

$h^{i}\left(z_{t}^{s}\right)$ : 各パスの投資量関数 (設定方法は 3.1 節参照)

(5) 定式化

$$
\begin{aligned}
& \text { 最大化 } \quad \frac{1}{I} \sum_{i=1}^{I} U\left(W_{T}^{i}\right) \\
& \text { 制約条件 } \\
& \qquad \begin{aligned}
W_{1}^{i} & =\left\{\rho_{1}^{i}-(1+r) \rho_{0}\right\} z_{0}+(1+r) W_{0} \\
W_{t}^{i} & =\left\{\rho_{t}^{i}-(1+r) \rho_{t-1}^{i}\right\} h^{i}\left(z_{t-1}^{s^{\prime}}\right)+(1+r) W_{t-1}^{i} \\
& \left(t=2, \ldots, T ; s^{\prime} \in S_{t-1} ; i \in V_{t-1}^{s^{\prime}}\right)
\end{aligned}
\end{aligned}
$$

(6) 目的関数に関する追加事項

CRRA 型効用を最大化する場合, 効用を式 (2.23)のように定義する.

$$
U\left(W_{T}^{i}\right)=\frac{\left(W_{T}^{i}\right)^{1-\gamma}}{1-\gamma}
$$

11本研究では CRRA 型の場合は $W_{T}^{i}$ を決定変数として定義し, LPM $(1)$ 最小化の場合は $W_{T}^{i}$ 決定变数とし て定義しない実装としている。これらは計算速度に関わる要素である. 
LPM(1) を最小化する場合，効用を式 (2.24) で定義する.

$$
U\left(W_{T}^{i}\right)=-\max \left\{W_{G}-W_{T}^{i}, 0\right\}=-\min \left\{q^{i} \mid W_{T}^{i}+q^{i} \geq W_{G}, q^{i} \geq 0\right\}
$$

CRRA 型効用を利用する場合，最終時点の富が正の值を持たないと効用を定義できない ため，最終時点の富が正となる制約式 $\left(W_{T}^{i} \geq \epsilon>0\right)$ を含める必要がある. また，期中の富 $W_{t}^{i}$ がマイナスになるのも回避する制約式 $\left(W_{t}^{i} \geq 0, t=1, \ldots, T-1\right)$ を追加するべきだが, 計算速度が遅くなるので無視する，一方，LPM(1) を最小化する場合は期中の富に関する制 約がなくても解を求めることができるため，本研究では利用していない.

\section{3. 提案モデルの概要}

枇々木 $[11,14]$ の混合型モデルはパスごとに異なる意思決定 (条件付き意思決定) を厳密に行 えず，同一ノードでは同一の意思決定であること，同一の意思決定を投資比率とするならば， ノードの切れ目で投資比率が変わってしまうことを問題点として抱えている，ノード分割を 大量に行えば，これらを無視できるが，問題規模が増大するため求解は困難になる．本研究 では枇々木 [13], Hibiki [14] の投資量関数をもとに，解析解の特徴である状態変数の連絸関 数を用いて，離散時間で状態に依存した最適な意思決定が実現可能なモデルを提案する.

\section{1. 状態に依存した最適な意思決定を可能にする投資量関数の設定}

各サンプルパスにおける最適投資比率を考える．時点を $t$ に固定する．投資比率決定戦略の 混合型モデル (混合型投資比率決定モデル) は各パス $i \in V_{t}^{s}$ において同一の意思決定を行う モデルである．たとえば，サンプルパスが 1000 本で各時点で意思決定ノードを 4 つに等分割 するとしよう，この場合，意思決定ノード $s$ には 250 本のサンプルパスが入るが，この 250 本においては同一の意思決定が行われる。一方，250本のサンプルパスにおいて，まったく 同じ状態のものは一つもないため，状態に応じた意思決定を厳密に行うことはできない(意 思決定をパスごとに定義すると非予想条件に反する). 説明のため, 2.1.1 項と同一の設定と し，時間が連続であることは無視したものを例とする．ある時点 $t$ を取り出すと，サンプル パスごとに状態価格の值が違うため, 最適投資比率 $\pi_{t}$ はパスごとに異なり, 解は 1000 通り ある. 一方，意思決定ノードはパス数に比べて少ないため，ノードごとの投資比率を決定す る方法では 1000 通りの解を導出することはできない.

そこで，以下の手順で最適意思決定をサンプルパス (状態)ごとに設定可能になるように 書き換える. 時点 $t$, パス $i$ における最適意思決定 $\pi_{t}^{i}$ が状態変数 $x_{t}^{i}$ によって求まるとして, 関数 $f_{t}$ を利用して記述すると, $\pi_{t}^{i}=f_{t}\left(x_{t}^{i}\right)$ となる.ここで, $\pi_{t}^{i}=f_{t}\left(x_{t}^{i}\right)$ を $x_{t}^{*}$ 周りでテイ ラー展開すると式 (3.1)のようになる.

$$
\pi_{t}^{i}=f_{t}\left(x_{t}^{i}\right)=f_{t}\left(x_{t}^{*}\right)+\frac{d f_{t}\left(x_{t}^{*}\right)}{d x}\left(x_{t}^{i}-x_{t}^{*}\right)+O\left(\left(x_{t}^{i}-x_{t}^{*}\right)^{2}\right)
$$

関数 $f_{t}$ の形状は特定できないが, 最適化に組み込むことで関数の形状や微分の值を特定 する必要はなくなる．本研究では一次までテイラー展開する．これは先行研究における解の 性質を考慮した上で，さらに最適化計算のオーバーフィッティングを回避するためである. Kim and Omberg [16]は (ボラティリティが一定ならば) 最適投資比率が状態価格の一次式で あると示しており，状態価格を $x_{t}^{i}$ とすれば解が一致する．また，一期間問題における平均・ 分散モデルも空売りの制約がなければ投資比率は期待リターンの一次式であり, 期待リター 
ンを $x_{t}^{i}$ とすれば二次の誤差は無視できる. 一方, Cvitanić and Karatzas [7] では投資比率は その時点の富が正規分布のパラメータとして利用される複雑な関数であり, 一次式では表せ ない. そのため, より高次元の展開をすることで精度が高くなる可能性もあるが, その場合 でも一次式を利用した方が現実的である.これは, 富と投資比率の関係の形状および投資比 率を状態に応じて単調増加 (もしくは単調減少) させるためである. 富と投資比率の関係を 調べると一次式での近似は十分可能である (図 8 の解析解を参照のこと). 二次式の場合, 係 数条件によっては投資比率が単調増加 (減少) でなくなる恐れがある. 数值解法を行う場合, 発生させたサンプルにとって最適な值を出力してしまう．すなわち，関数が複雑になると， オーバーフィッティングが起き，係数条件を满たさない可能性がある．そのため，二次式に するよりはノードを分割し，各ノードにおいて一次式による最適化を行う方が係数条件を満 たしやすく, 現実的な解を求めやすい。これらの理由から, 投資比率については一次までの テイラー展開で十分であると判断する.

時点 $t$, パス $i$ において, $x_{t}^{i}$ が既知であるとすれば, 非予想条件に違反しない定式化が可 能である. 将来リターンそのものは既知ではないが, 確率分布のパラメータやその時点で保 有する富は既知とみなしても一般性を失わない. 状態変数 $x_{t}^{i}$ として, 過去の情報 (過去リ ターンなど)を利用することも可能である.

式 (3.1) では投資比率を状態変数の関数としたが, 投資額や投資量を状態の関数とみなすこ ともできる.この情報を Hibiki [14] の混合型モデルで利用する. ベース投資量を $z_{t}^{s}=x_{t}^{i} b_{t}^{s}+c_{t}^{s}$ に書き換え, 式 $(2.22)$ の投資量関数 $h^{i}$ に代入する. 決定変数は $z_{t}^{s}$ ではなく $b_{t}^{s}, c_{t}^{s}$ になる. 最 適化問題は式 $(3.1)$ の $x_{t}^{i}$ の係数を推定する問題とほほ一致する (二次のオーダーの誤差はす べて定数項に入る). それぞれの投資量関数は以下の通りである.

- 投資額決定モデル : $h^{i}\left(z_{t}^{s}\right)=\left(\rho_{0} / \rho_{t}^{i}\right) z_{t}^{s}=\left(\rho_{0} / \rho_{t}^{i}\right)\left(x_{t}^{i} b_{t}^{s}+c_{t}^{s}\right)$

- 投資量決定モデル : $h^{i}\left(z_{t}^{s}\right)=z_{t}^{s}=x_{t}^{i} b_{t}^{s}+c_{t}^{s}$

- 投資比率決定モデル : $h^{i}\left(z_{t}^{s}\right)=\left(W_{t}^{i, 0} / \rho_{t}^{i}\right) z_{t}^{s}=\left(W_{t}^{i, 0} / \rho_{t}^{i}\right)\left(x_{t}^{i} b_{t}^{s}+c_{t}^{s}\right)$

投資比率決定モデルに用いる $W_{t}^{i, 0}$ は，最適化の結果求まる $W_{t}^{i}$ ではなく，入力パラメー 夕で, 数値計算上は反復計算の一回前の值を利用している. Hibiki [14] との違いはノード分 割のみに利用していた状態変数 $x_{t}^{i}$ の情報を決定変数の係数として利用している点である. なお， $x_{t}^{i}$ はノード分割に利用する值である必要はないが，本研究のモデルでは同一とする.

このモデルは混合型最適化モデルの投資量関数を書き換えただけであり，混合型モデルの 自然な拡張である. 混合型モデルとの違いをテイラー展開の次数の面から説明する．シミュ レーション型モデルは代表的な $x_{t}^{*}$ 周りで 0 次のテイラー展開が行われたものである. 混合 型モデルは展開位置がノード集合によって異なる方法であり，テイラー展開の次数は 0 次 のままのモデルとなる。線形近似モデルはさらにノードごとに一次関数を設定することで， 最適投資戦略の誤差を小さくしている，仮にすべての状態で同じ意思決定が最適解であるよ うな設定 (利用した状態変数に非依存な設定) をしても， $b_{t}^{s}=0$ と一致するため，解は必ず 良くなる，そのため，実用上は決定変数が増えることによる悪影響以上に解が良くないと， 関数を導入する利点はない.

他の先行研究としては, Calafiore [5] が多期間平均・分散モデルにおいて, 最適投資額が 過去のリターンの一次式とみなす方法を採用しており, 解の改善を示している. 本研究はモ ンテカルロ・シミュレーションを採用し, 目的関数を拡張可能な方法で適用したこと, 混合 型モデルをベースにしたことで，関数の形状がどのような場合でも一次式の組み合わせによ る求解を可能にした点が大きな違いである. 
一次式による投資量関数の設定を行ったため, 本研究で提案するモデルを線形近似モデル と呼ぶ. シミュレーション型の場合はシミュレーション型線形近似モデル，混合型の場合は 混合型線形近似モデルとする.

\section{2. 区分線形近似モデルの定式化}

本研究で提案した線形近似モデルはノードごとに独立して決定変数を利用する，そのため， ノードが変わる際に投資量関数が非連続になる可能性を排除できていない.そこで，状態 $x_{t}^{s_{1}, s_{2}}$ を境にノード $s_{1}$ とノード $s_{2}$ を分けた場合，状態 $x_{t}^{s_{1}, s_{2}}$ で $z_{t}^{s}$ を一致させる制約を入れ ることで投資量関数を連続にできるようにする。このモデルを区分線形近似モデルと呼ぶ. 区分線形近似の場合，ノード分割が必須となるため，混合型モデルと同様の定式化に加えて 同一投資比率になるための制約が必要となる．その制約は式 (3.2) で表される.

$$
x_{t}^{s_{1}, s_{2}} b_{t}^{s_{1}}+c_{t}^{s_{1}}=x_{t}^{s_{1}, s_{2}} b_{t}^{s_{2}}+c_{t}^{s_{2}}
$$

各モデルの違いを図 1 に示す．図中の凡例名は表 3 で示す．

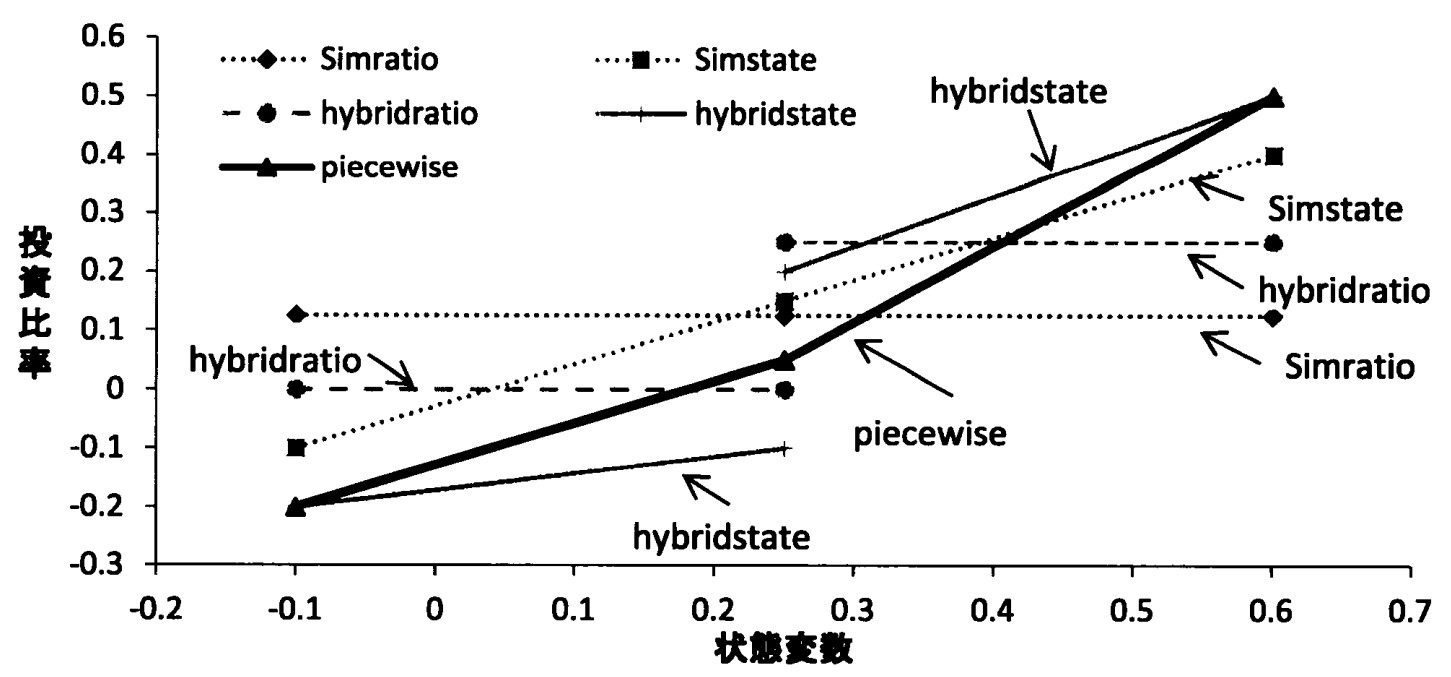

図 1: 最適化モデルによる状態と投資比率の関係

図 1 は極端な場合を例示している．区分線形近似モデルと混合型線形近似モデルの違い は発生させたサンプルとノードの分割方法に依存する．区分線形近似は投資量のベースと なる基碟変数值 (投資比率の近似値)を一致させる制約であるため, 計算過程の近似精度に よっては投資比率は非連続になる。混合型モデルはノードの分割点 (図 1 の場合, 状態变数 が 0.25) で值が大きく変わり，それ以外では同一の投資比率であるため，仮に状態変数が期 待リターンである場合には厳密ではない。

\section{3. モデルの計算方法}

各最適化モデルは表 3 に示すモデルを対象とする. 図表表記において, Sim-がシミュレーショ ン型(ノード分割せず)，hybrid-が混合型(ノード分割を行う)，-ratioが投資比率近似，-state が線形近似 (提案手法の利用)を意味する. 区分線形近似は, piecewise と表記する.

計算アルゴリズムはモデルにより異なり, 表 3 の右から 2 列に示す. CRRA-2であれば, 以下に示す計算アルゴリズムの中の CRRA 型の場合の手順 2 だけ (投資比率近似計算だけ) を利用し，LPM-1345であれば，LPM(1)の場合の手順 1，3，4，5を利用する(線形近似は 
表 3: 比較対象とする最適化モデル

\begin{tabular}{c|c|c|c|c}
\hline & モデル名 & 図表表記 & \multicolumn{2}{|c}{ 計算アルゴリズム } \\
\hline \multirow{2}{*}{ 先行研究 } & シミュレーション型投資比率 & Simratio & CRRA-2 & LPM-135 \\
\cline { 2 - 5 } & 混合型投資比率 & hybridratio & CRRA-12 & LPM-1235 \\
\hline \multirow{2}{*}{$\begin{array}{c}\text { 線形近似 } \\
\text { モデル }\end{array}$} & シミュレーション型線形近似 & Simstate & CRRA-23 & LPM-1345 \\
\cline { 2 - 5 } & 混合型線形近似 & hybridstate & CRRA-123 & LPM-12345 \\
\cline { 2 - 5 } & 区分線形近似 & piecewise & CRRA-123 & LPM-12345 \\
\hline
\end{tabular}

行うが, 手順 2 のノード分割は行わない)ことを意味する. なお，比率近似，線形近似計算 の際，反復計算を行うことで計算結果を安定させることができる.

- CRRA 型の場合の手順

1.ノードを分割する

2. 投資量モデルの解を $W_{t}^{i, 0}$ として投資比率近似計算する

3. 手順 2 の解を初期值として, 線形近似計算を行う 12

- $\operatorname{LPM}(1)$ の場合の手順

1. シミュレーション型投資量モデルの解を $W_{t}^{i, 0}$ とする

2. 手順 1 の結果をもとに各時点のノードを分割し, 混合型投資量モデルを解く

3. 最新の富の值を $W_{t}^{i, 0}$ にし，投資比率近似を行う

4. 手順 3 の結果を $W_{t}^{i, 0}$ に利用し, 線形近似，区分線形近似を行う

5. 目的関数值が収束すれば終了，していなければノードを再分割して手順 3 に戻り, 反復計算する

CRRA 型では， $W_{T}^{i}$ の初期値を設定する必要がある $\left(W_{T}^{i}=0\right.$ を初期值とすると効用を定 義できない). 本研究においてはリスク資産の投資量を 0 (投資比率を0) として計算した最 終富 $\left(W_{T}^{i}=W_{0}\left(1+R_{f}\right)^{T}\right)$ を初期值とし, 2 回目以降はひとつ前の計算結果を初期値として 計算する．比率近似の富 $W_{t}^{i, 0}$ は各手順で更新する．LPM(1) ではその富の值をノード更新 にも利用するが, 手順 3,4 ではノード更新はおこわない.

混合型の意思決定ノードは Bogentoft, Romeijn and Uryasev [3] が提案した格子タイプを 利用する.ノード分割は状態 (状態変数 $X_{t}$ もしくは富 $W_{t}$ ) の相対水準で均等分割する.

\section{4. モデルの誤差要因}

最適解に対する提案モデルの誤差要因をまとめると以下の点が考えられる.

1. 式 (3.1)のテイラー展開の打切り誤差

2. 状態変数の定義による誤差

3. 微分不可能な投資比率に対してノード分けを行う際, 最適でない誤差

4. 投資比率を近似解法で求める誤差 (富を反復計算で求める誤差)

5. (非線形最適化の場合) 大域的最適解の導出が保証されないことによる誤差

6. シミュレーションパスの誤差

CRRA 型で調べることによって，要因 $1 ， 2 ， 3$ の誤差をほほ 0 にできる．つまり，モデ ルの誤差要因は比率近似の精度, アルゴリズムの精度, サンプル誤差の 3 つにすることがで きる.

12線形近似計算は投資比率近似した值を初期值とする必要性はなく，投資量モテルの值を直接利用することも 可能である. 本研究では, モデル間の差を減らした比較を行うため,この計算方式を探用している。 
比率近似の精度はパラメータによって大きく変わるため, 必要に応じて議論する。なお, LPM(1)の場合は線形計画問題であるため, 要因 5 をほほ無視できる代わりに要因 1,3 を無 視できない. 本研究の数值分析では，CRRA 型では状態価格を， LPM(1) 最小化では富を利 用すればよいことが分かっているため，基本的に要因 2 の問題は起きない. ただし，LPM(1) では状態変数である富が最適化を行うごとに変わってしまうため, それが誤差として出て くる.

\section{4. 数值分析：CRRA 型期待効用最大化問題}

CRRA 型期待効用最大化問題において, 3 種類のアプローチ (解析解, モンテカルロ回帰, 確率計画モデル) との比較を通じて線形近似モデルの性質を確認する. 特に記載のない場合, サンプルパスは 4000 本とする，計算結果は，乱数シードを変えたシミュレーション 100 回 の平均の目的関数值と 0 時点投資比率を示している.ただ，状態変数と投資比率の関係に ついては適当な 1 シードの結果のみを示した。これは LPM $(1)$ の場合も同じである. 線形近 似モテルにおける状態変数 $Z_{t}$ には，モンテカルロシミュレーションで発生した状態価格 $X_{t}^{i}$ を用いる。

\section{1. 設定}

\subsection{1. モデル比較の対象}

2.1.1 項の解析解 (3 種類の計算方法), 2.2.1 項のモンテカルロ回帰 (2 種類), 3.3 節の表 3 の 確率計画モデル (5 種類) の計 10 種類を比較対象として計算する. 表 4 にまとめて記載する.

表 4: CRRA 型期待効用最大化問題：比較対象

\begin{tabular}{|c|c|c|c|}
\hline モデル & 図表表記 & 計算方法 & 参照 \\
\hline \multirow[t]{3}{*}{ 解析解 } & KimOmberg & Kim and Omberg [16] の解析解 & \multirow[t]{3}{*}{2.1 .1} \\
\hline & dynamic & 連続時間解析解を離散時間にあてはめ & \\
\hline & myopic & 近視眼的解を離散時間にあてはめ & \\
\hline \multirow[t]{2}{*}{ MCR } & MCR0 & 金利周りテイラー展開 & \multirow[t]{2}{*}{2.2 .1} \\
\hline & MCRmyopic & 近視眼的ポートフォリオ周りでテイラー展開 & \\
\hline \multirow[t]{2}{*}{ 投資比率モデル } & Simratio & シミュレーション型投資比率 & \multirow[t]{2}{*}{2.2 .2} \\
\hline & hybridratio & 混合型投資比率 & \\
\hline \multirow{3}{*}{$\begin{array}{c}\text { 線形近似モデル } \\
\text { (提案モデル) }\end{array}$} & Simstate & シミュレーション型線形近似 & \multirow[t]{3}{*}{3.3} \\
\hline & hybridstate & 混合型線形近似 & \\
\hline & piecewise & 区分線形近似 & \\
\hline
\end{tabular}

比較対象の 10 個のうち, 解析解 [KimOmberg] はパラメータを代入して求めた目的関数と 0 時点投資比率を求める。 それ以外はモンテカルロシミュレーションで発生したサンプルパ スによってこれらの值が計算される.

解析解 [dynamic] について説明する．時点 0 において状態変数が与えられれば，式 (2.7) より解析解が求まる.これは連絸時間の解であるが, それを無視して解析解と同じ投資比率 で $\Delta t$ だけ運用し， $\Delta t$ 経過後, 更新された状態変数, 残存期間から再び求めて運用するとい うことを繰り返して期待効用を計算する. なお, [myopic] は解析解の近視眼的部分 $\frac{X_{t}}{\gamma \sigma}$ のみ で同じことを行う. [KimOmberg] と [dynamic] は，特定の時点およびパスにおける投資比率 は同じだが，期待効用值は連続時間リバランスの効果の分， [KimOmberg] が良くなる. 
考察の際，表 4 左端のモデルの名称と図表表記を組み合わせて利用する. 線形近似 [-state, piecewise] と表記する場合, Simstate, hybridstate, piecewiseいずれにも共通の考察を示す. 線形近似 [-state] の場合は, piecewise には関係がない記述であることを表す．表記の接頭語， 接尾語のルールは 3.3 節で示したものと同じである.

\subsection{2. 感度分析パラメータ設定}

ノード数, 時間間隔 $\Delta t$, リスク回避度 $\gamma$ に対する感度分析を行う. それぞれケース 1 ケケー ス 3 と呼ぶ. 感度分析するパラメータ変動の範囲を表 5 に示す. 満期は 2 年とする. 対象パ ラメータ以外は固定して行う. 混合型の基準ノード数を 2 としたのは線形近似モデルと変数 の数を一致させるためである.

表 5: CRRA におけるパラメータセット

\begin{tabular}{c|c|c|c|c}
\hline & 変数 & 基準值 & 変化させる範囲 & 刻み幅 \\
\hline ケース 1 & ノード数 & 2 & $1,2,4,5,8,10$ & - \\
\hline ケース 2 & $\Delta t$ & $\frac{1}{4}$ (四半期) & $\frac{1}{2}, \frac{1}{4}, \frac{1}{6}, \frac{1}{12}, \frac{1}{24}$ & - \\
\hline ケース 3 & $\gamma$ & 10 & $2 \sim 10$ & 1 \\
\hline その他 & 固定 & $r=0.05, \quad \lambda_{x}=0.2, X_{0}=\bar{X}=0.25, \sigma_{x}=0.2, \sigma=0.2, \rho=-0.5$ \\
\hline
\end{tabular}

\section{2. 感度分析結果}

各パラメータの感度分析の結果を示す。なお, 考察内では表記の簡便化のため, 運用開始か ら $\Delta t$ だけ経過した時点を 1 時点, 最終時点を $T$ 時点, その $\Delta t$ 前を $T-1$ 時点と示す. 満 期 $T$ は式 (2.7) で利用する単位 (年) ではなく，多期間モデル内における時点表記である.

解析解からの相対值を用いて期待効用と 0 時点投資比率の比較をする場合，期待効用の 相対值は $U_{d}=\left(U_{0}-U_{1}\right) / U_{0}\left(U_{0}\right.$ : 解析解の期待効用, $U_{1}$ : 比較対象), 投資比率の相対值は $x_{d}=\left(x_{1}-x_{0}\right) / x_{0}$ ( $x_{0}$ : 解析解の投資比率, $x_{1}$ : 比較対象) とする.

\subsection{1. ケース 1 : ノード数の違いによる比較}

6 種類のノード数に対する結果を比較する。ノード数を増やした際の精度を上げるため，サ ンプルパスは 10000 本とする. 図 2 に期待効用值と 0 時点投資比率を示す. 意思決定ノード 数inf は連続時間解析解を離散的に割り当てた [dynamic] 示す. MCR はモンテカルロ回帰 により計算した値を示す．図表内では，シミュレーション型はノード数を 1 ，混合型はノー ド数を 2 以上に割り当てている．グラフ内の実線は連続時間解析解 [KimOmberg]による期 待効用值と投資比率を，破線は近視眼的解 [myopic] 割り当てた場合の期待効用值を示して いる。棒グラフは, 左から ratio, state, piecewiseの結果を示し, MCRでは左から MCR0, MCRmyopic を表記している.

期待効用について比較する。線形近似 [-state, piecewise] はシミュレーション型 [Simstate] でも近視眼的解 [myopic]より期待効用は高い.しかし，ノード数 10 の混合型線形近似モデ ル [hybridstate] は解析解の期待効用值を超えており，サンプリングエラーの影響を受けてい ることが分かる ${ }^{13}$. 投資比率モデル [-ratio] の場合，ノード分割を 5 個以上行わないと近視 眼的ポートフォリオ [myopic] より期待効用が低いため，線形近似による期待効用の増加の

\footnotetext{
13意思決定のノード数を 10 倍にしたため, ノード数を 1 とした場合と同等の精度を出すには 100 倍のサンプ ルパスが必要であると考えられる。ノード数 10 においては，たとえ推定誤差を考慮に入れても解析解の期待 効用值を上回ったが，この理由は最適化がオーバーフィッティングを起こしやすいためである．問題設定上は このようなことは起こらない。
} 


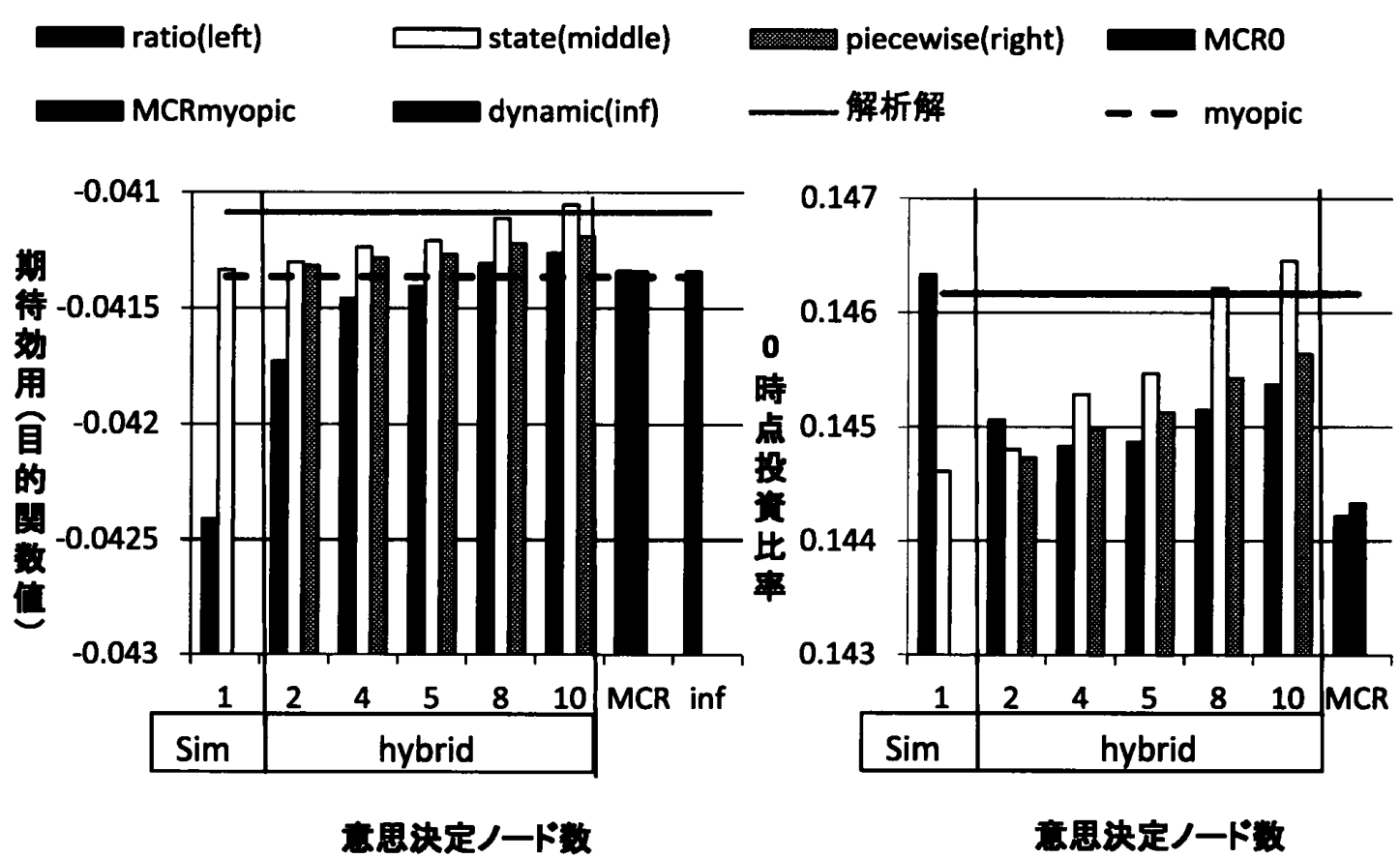

図 2: 意思決定ノード数の違いによる期待効用 (左) と 0 時点投資比率 (右)

効果があることがわかる. 線形近似 [-state, piecewise]においてはノード数を増やす効果は 混合型投資比率 [hybridratio] に比べて小さく，線形関数の導入の影響の方がノード分割より 大きい. これは投資比率が状態変数の一次式である CRRA 型の特徴であるといえる.MCR とシミュレーション型線形近似 [Simstate] の差はほとんどなく，どちらのモデルでも実用的 には問題ないといえる.

0 時点投資比率について比較する．線形近似 [-state, piecewise] はノード数が増えるほど 0 時点投資比率が高くなる. 一方, 投資比率モデル [-ratio] はノード数 4 まで投資比率が下 がり，その後は上昇するため単調増加ではないが，この理由は不明である．ただし，近視眼 的解 [myopic] の投資比率は 0.125 である (值が小さく，図 2 には含まれない)が，その他の投 資比率の各モデル間での差は $0.2 \%$ 程度である.

混合型線形近似 [hybridstate] におけるノード分割効果を見るため, 将来時点の投資比率 を比較する. 1 時点と $T-1$ 時点の状態変数 $X_{t}$ と投資比率の関係を図 3 に示す. 図の横軸 の POR は状態変数 $X_{t}$ の各時点, 各パスでの值, 縦軸は最適投資比率を示す. 凡例の数值 はノード分割数を示す.

グラフでは，シミュレーション型線形近似 [Simstate] は一直線になっている，ノード分割 を行うと，ノードの分割点で大小関係が不整合になり解析解と一致しない. 乱数を变えても 同じような結果が出やすい. 解析解 [KimOmberg] は状態変数の線形関数であることを考慮 に入れると，シミュレーション型線形近似 [Simstate] が最も現実的な解になっている. 図に 示していないが, 解析解はほとんど線形近似 [Simstate] と同じ值であり，仮にプロットして も多くの部分で重なる。

0 時点投資比率，期待効用，期中の POR と投資比率の関係のいずれを見ても，線形近似 においてノード分割を行う効果は少なく，むしろサンプリングエラーを起こす原因になって いる. 紙面の都合上示していないが, 最終時点における富の分布もほとんど変わらない。こ れらを踏まえ, CRRA 型期待効用に関する以降の分析では, シミュレーション型線形近似 

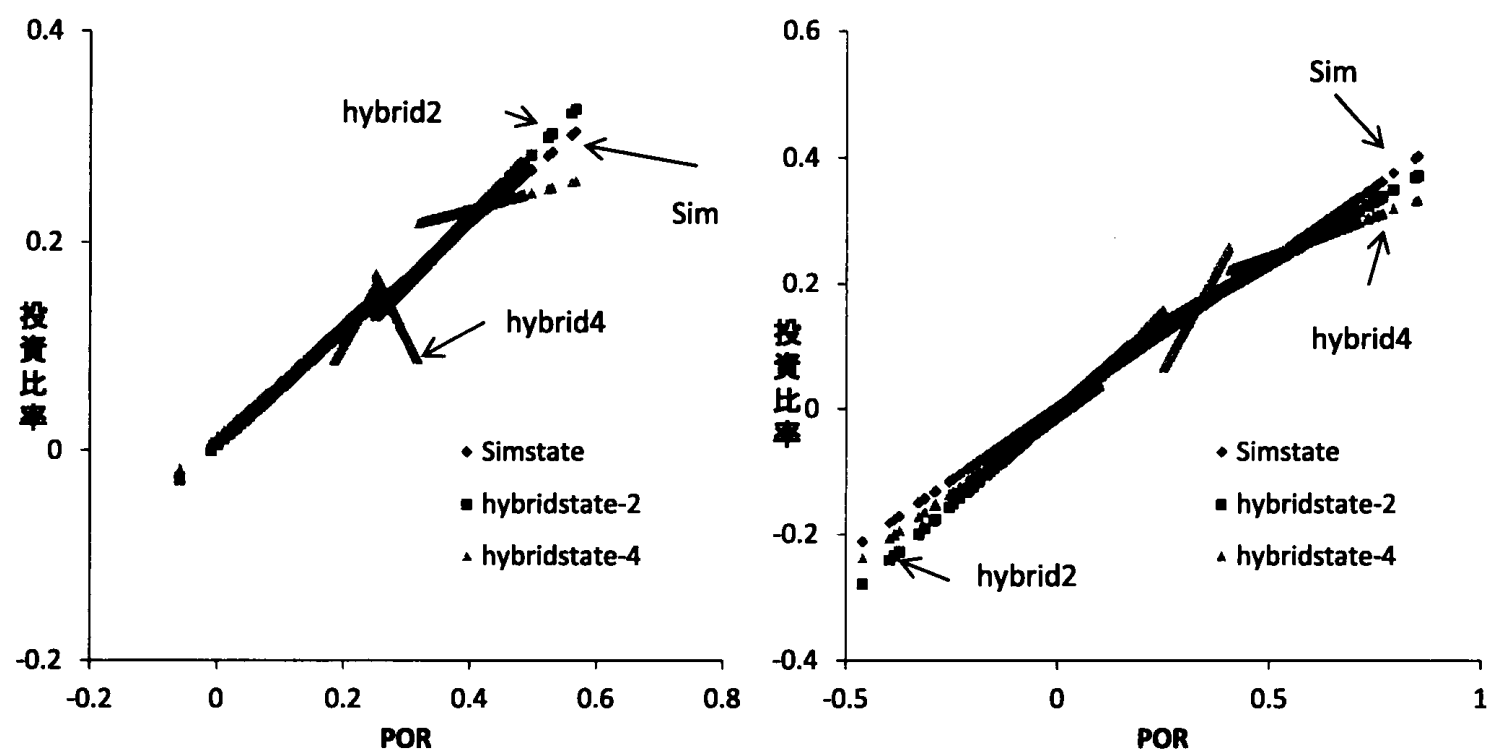

図 3: 1 時点 (左) と $T-1$ 時点 (右)における POR と投資比率の関係

モデル [Simstate], 投資比率モデル [-ratio], MCR との比較を中心に行う.

\subsection{2. ケース $2:$ 連続時間の解との比較 $(\Delta t$ による違い)}

$\Delta t$ を変えた場合の期待効用値と 0 時点投資比率を図 4 に示す．図には示していないが，混 合型線形近似 [hybridstate, piecewise] は $\Delta t$ が小さくなると解析解より期待効用が高くなる ため，オーバーフィッティングが生じている．シミュレーション型投資比率 [Simratio] の期 待効用值は $\Delta t$ によらず -0.0424 程度で, 他のモデルより低いため省略する．MCR はどち らもほほ同じ結果なので, 金利周り [MCR0]のみ示す。

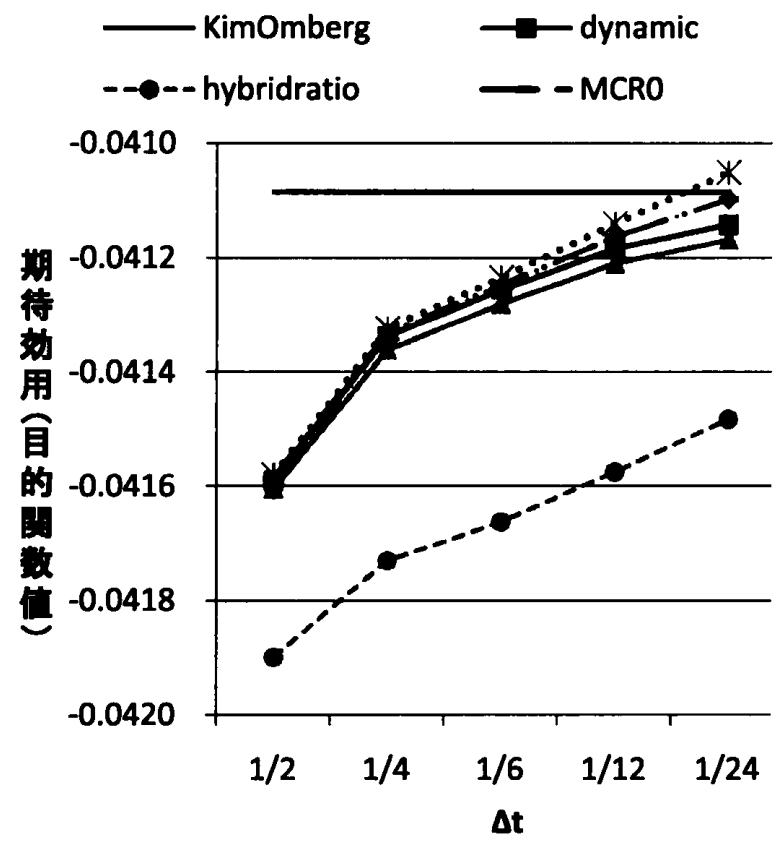

$\longrightarrow$ myopic $\quad \cdots * *$ Simstate

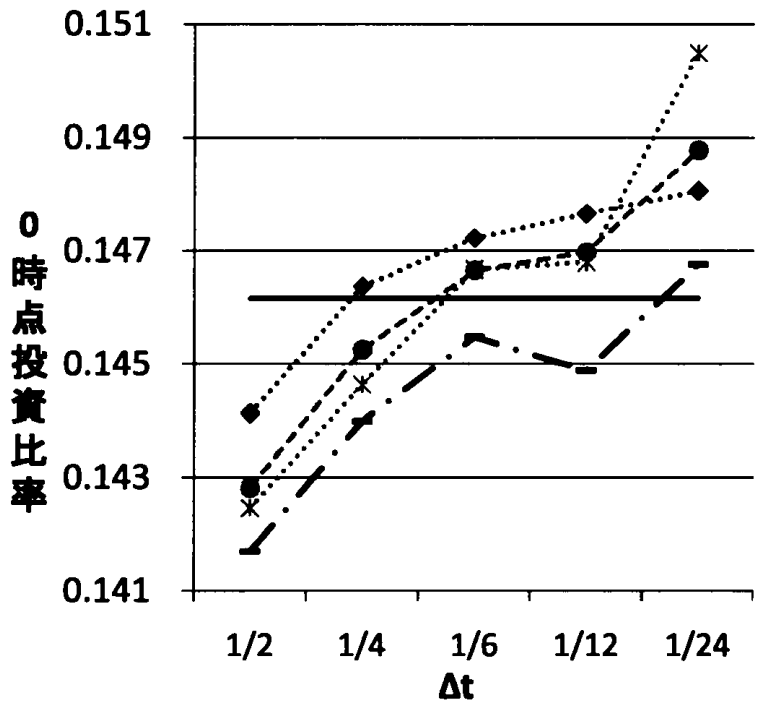

図 4: $\Delta t$ による期待効用の変化

解析解の割り当て [dynamic, myopic] はノード数を比較したときと同様，投資比率の差 
([dynamic] は 0.146, [myopic] は 0.125) に比べて期待効用の差がほとんどなく，0時点投資 比率の影響は小さい．そのため, 確率計画モデルでは連続に近づくほど 0 時点投資比率が高 いものの, 期待効用の增加は期中のリバランスの影響が大きい. MCR では $\Delta t$ と投資比率 の関係が単調ではないことも考慮に入れると，CRRA 型効用では 0 時点投資比率が多少ず れても問題なく，その值は計算方法や初期值に依存することが確認できる.

線形近似 [Simstate] は MCR とほほ同等の解を導出でき, 混合型 [hybridratio] よりも目的 関数が高くなる. ただし， $\Delta t=\frac{1}{24}$ では線形近似 [Simstate] においてオーバーフィッティン グが生じている．モデルとして連続的なリバランスを想定していないこと，時点数を増やし た分だけサンプルパスを增やさなくてはいけないことから，このような場合にはうまくいか ない ${ }^{14}$.この解決策として，時点についてもテイラー展開をする方法もあるが，これについ ては本研究では検証をしていない.

\subsection{3. ケース 3：リスク回避度}

図 5 に 9 種類のリスク回避度 $\gamma$ に対する期待効用と投資比率の解析解からの相対值を示す.

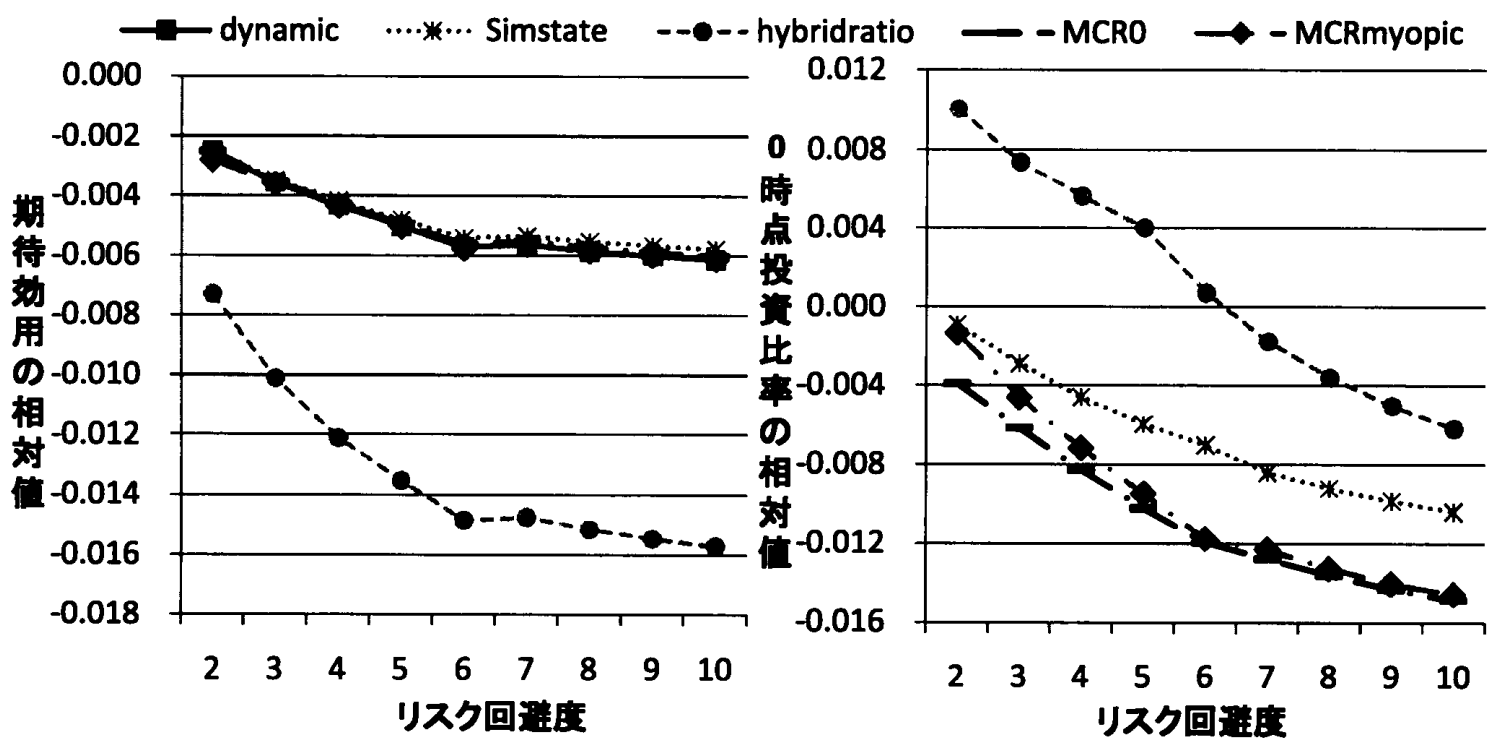

図 5: リスク回避度の違いによる期待効用値 (左) と 0 時点投資比率 (右) の相対値

線形近似 [Simstate] と MCR, 解析解の割り当て [dynamic] の期待効用の差はほとんどな い. 図では分かりにくいが，リスク回避度 $\gamma$ が高いほど線形近似 [Simstate] が有利になる. 一方，混合型投資比率 [hybridratio] はリスク回避度が高くなると，他のモデルょりも急速に 解が悪化する．これはリスク回避度 $\gamma$ が高いほどダウンサイド側の影響が大きくなり，ノー ド数が 2 個では対応が難しくなるためである.

線形近似 [Simstate] と MCR の違いを調べるために, $\gamma=2$ の場合の状態変数 $X_{t}(\mathrm{POR})$ と投資比率 $\pi_{t}$ の関係を図 6 に示す。

1 時点では違いは少ないが, 時点 $T-1$ ではモデルによって異なる傾向を示している. MCR の場合, 特に近視眼的ポートフォリオ周り [MCRmyopic] は POR と投資比率の関係が非線 形かつ非単調増加になる．一方，線形近似 [Simstate] は投資比率が1を超える領域でプロッ

14サンプルパスが足りないと，期中で POR と投資比率の関係が逆転する (POR が高い方が投資比率が低くな る)解を出すこともある。 

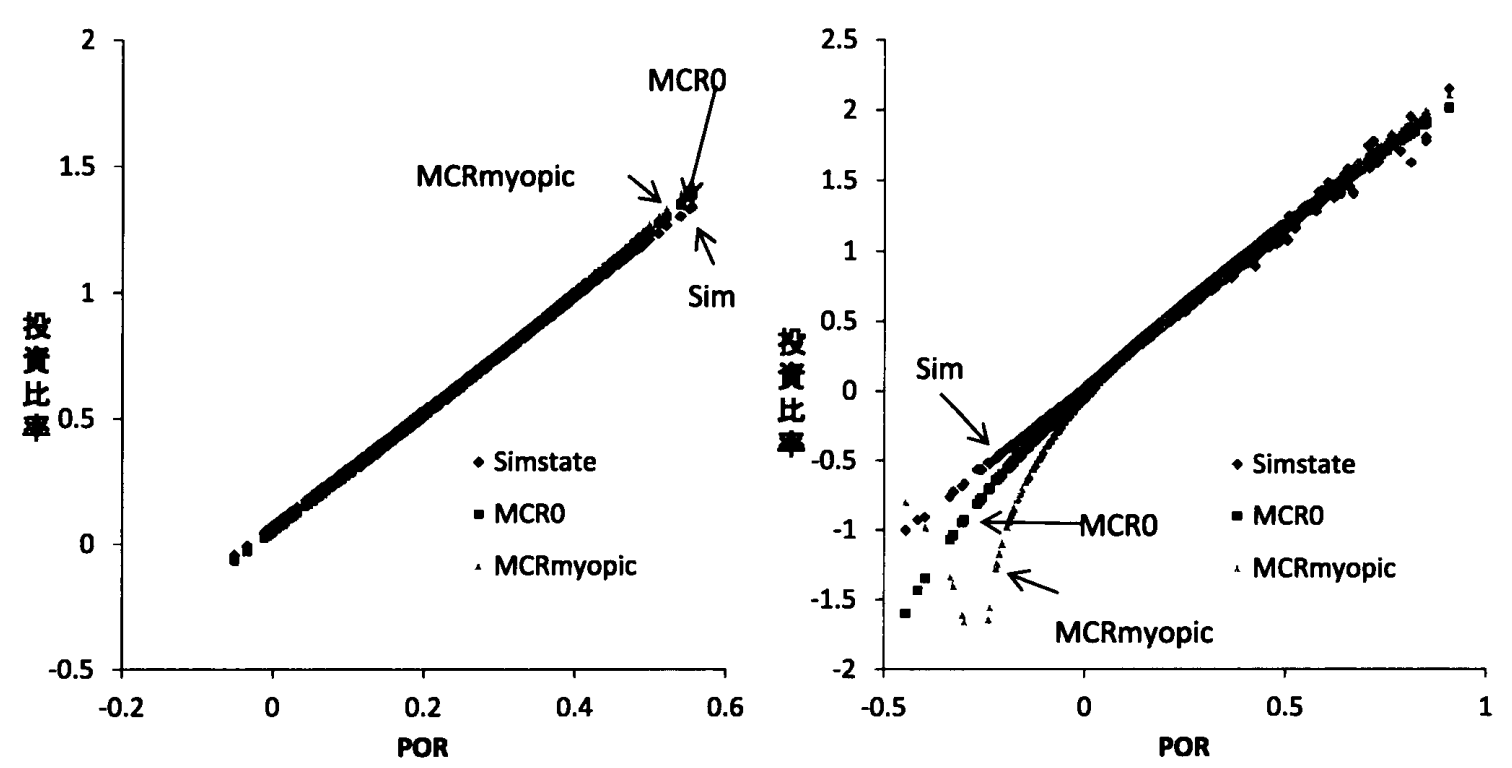

図 6: 1 時点 (左) と $T-1$ 時点 (右)の POR と投資比率の関係

トが線形ではなく，POR と投資比率が一対一対応しなくなる (4.3.2 項参照). いずれもリス ク回避度 $\gamma=10$ ではなかった傾向である.

\section{3. 考察}

\subsubsection{MCR と線形近似モデルの違い}

MCR は効用関数を投資比率でテイラー展開し, 式中に出てきた条件付き期待值を一次式で 最小二乗推定することによって最適解を求める。一方, 線形近似モデルでは最適投資比率を 状態価格でテイラー展開して最適解を求める. MCR はテイラー展開を打ち切った誤差に加 え, 複雑な条件付き期待值を状態価格で推定する誤差がある。これは条件付き期待值を状態 価格でさらにテイラー展開していることに相当するため，二重に打切り誤差が生じる．線 形近似モデルも投資比率に対して打切り誤差はあるが，少なくともCRRA 型効用の解析解 と同じ設定においては打切り誤差を無視できる。状態価格で直接テイラー展開を行うため, 違う值を利用することによる誤差もない.これらの理由から線形近似モデルの方が MCRよ り有利であり，高い期待効用を算出できるモデルとなる.

\subsection{2. 投資比率近似アルゴリズムの収束精度が悪い場合について}

リスク回避度を変えると，T-1時点で投資比率が状態価格と一対一で対応しなくなること がある.これは投資比率近似アルゴリズムの収束精度があまり良くない場合があるためで ある. 同一乱数シードでもパラメータを変えただけでこの現象が発生するため, 一部のパラ メータにおいては計算アルゴリズムがうまく機能していないパラメータがあると言える.

標準パラメータを用いた場合や 1 時点 (図 6 (左))では問題があるように見えないが, 投資 比率が高い場合や意思決定の回数が多い場合に発生する。一方，本研究で分析した範囲では 投資比率が 1 以下のとき，投資比率近似アルゴリズムは見かけ上機能している．そのため， 実務上空売り禁止制約を入れるなどによって投資比率を 1 以下にする場合の影響は少ないと 言える。 


\section{4. 結論}

期待効用 線形近似モデルの期待効用が他のモデルより最も高く，そのサンプルにおける理 論解に近くなる．ただし，オーバーフィッティングの発生も他より多い.

0 時点投資比率 モデルによる違いは少なく，実用上は従来の混合型モデルの值でも問題ない. 各時点の投資比率 線形近似モデルは状態変数と投資比率の線形・大小関係が保たれ，解析 解に近い.MCR は非線形な条件付き期待值を推定する必要があり，その誤差が大き いため，特に分布の端において不利である.

計算ソフトウェア MCR は回帰分析と方程式の数值解法のみで求解できるため, 高価なソ フトウェアは不要である．線形近似モデルは大規模な問題を解く必要があるため，強 力な数理計画ソフトウェアが必要になる.

その他 線形近似モデルは制約を入れることが容易なため，制約を含めることが難しい MCR

よりも一般的な場合では有利である，厳密には $W_{t}>0$ の制約が必要となるが, MCR ではこれを行う手段がないこと，初期值や計算方法をチューニングしなくても最適性 条件に一致する求解が可能なことも線形近似モデルの有利な点となる.

\section{5. 数值分析：LPM(1) 最小化問題}

LPM(1) 最小化問題に対する線形近似モデルの特徴を確認する．サンプルパスは 5000 本と する．MCRでは計算できないため，比較対象は解析解と確率計画モデルとする．線形近似 モデルにおける状態変数 $Z_{t}$ は富 $W_{t}^{i}$ を利用したいが，線形計画問題として定式化できない ため, 比率近似モデルと同様に反復計算の一回前の計算で求めた富 $W_{t}^{i, 0}$ を用いる.

\section{1. 設定}

\subsection{1. モデル比較の対象}

最適解の計算方法の比較対象として表 6 に記載したモデルを利用する．図表表記は，感度分 析の結果の凡例などに利用する.

表 6: LPM(1) 最小化問題：比較対象

\begin{tabular}{|c|c|c|c|}
\hline モデル & 図表表記 & 計算方法 & 参照 \\
\hline \multirow[t]{2}{*}{ 解析解 } & CK & Cvitanić and Karatzas [7] の解析解 & \multirow[t]{2}{*}{2.1 .2} \\
\hline & discCK & 連続時間解析解を離散時間にあてはめ & \\
\hline \multirow[t]{2}{*}{ 投資比率モデル } & Simratio & シミュレーション型投資比率 & \multirow[t]{2}{*}{2.2 .2} \\
\hline & hybridratio & 混合型投資比率 & \\
\hline \multirow{3}{*}{$\begin{array}{c}\text { 線形近似モデル } \\
\text { (提案モデル) }\end{array}$} & Simstate & シミュレーション型線形近似 & \multirow[t]{3}{*}{3.3} \\
\hline & hybridstate & 混合型線形近似 & \\
\hline & piecewise & 区分線形近似 & \\
\hline
\end{tabular}

\subsection{2. 感度分析パラメータ設定}

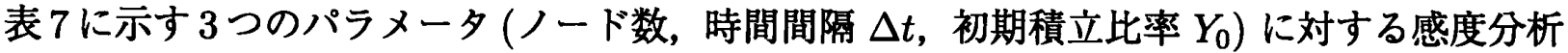
を行う。ノード数は線形近似モデルでは 2 ，投資比率モデルでは 4 を基準とする．なお，0 時点の富は $W_{0}=W_{G} Y_{0} \exp (-r T)(T$ は満期までの年数) としている. 
表 7: LPM(1) におけるパラメータセット

\begin{tabular}{c|c|c|c|c}
\hline & パラメータ & 基準值 & 変化させる範囲 & 刻み幅 \\
\hline ケース 1 & ノード数 & 2,4 & $1,2,4,5$ & - \\
\hline ケース 2 & $\Delta t$ & $\frac{1}{4}$ & $\frac{1}{2}, \frac{1}{4}, \frac{1}{6}, \frac{1}{12}, \frac{1}{24}$ & - \\
\hline ケース 3 & $Y_{0}$ & 0.95 & $0.6 \sim 0.99$ & 0.01 \\
\hline その他 & 固定 & \multicolumn{2}{|c|}{$r=0.05, \sigma=0.2, X=0.25, W_{G}=500$} \\
\hline
\end{tabular}

\section{2. 感度分析結果}

\subsection{1.ケース 1 ：ノード数の違いによる比較}

4 種類のノード数に対する目的関数の值と 0 時点投資比率を図 7 に示す. 図 7 の意思決定ノー ド数の inf は [discCK] を示す. 各ノード数に対して左から順に ratio, state, piecewiseの值 を示している.

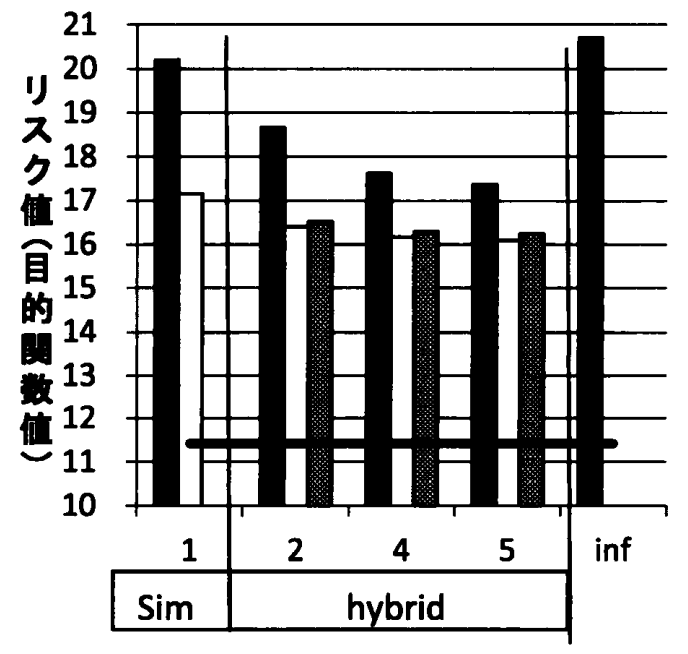

意思决定ノ一ド数

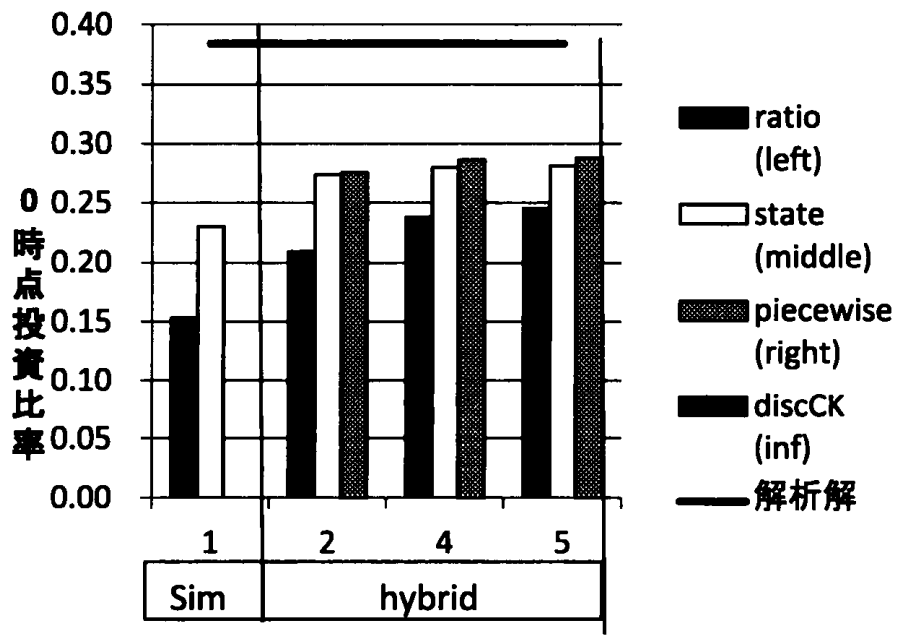

至思決定ノード搂

図 7:ノード数の違いによるリスク值 (左) と0 時点投資比率 (右)

線形近似 [-state, piecewise] は少ないノード数でも投資比率モデル [-ratio] よりリスクが 低くなり, 線形近似関数の効果が出ている. 線形近似 [-state, piecewise] の決定変数の方が 2 倍多いが，ノード数 2 の線形近似 [hybridstate, piecewise] の方がノード数 4 の投資比率モ デル [hybridratio]よりもリスクは低く，問題規模を考慮に入れても優れている.

各モデルの富と投資比率の関係を図 8 に示す. 区分線形近似 [piecewise] は混合型線形近似 [hybridstate] とほほ同様であるため, 混合型線形近似 [hybridstate] のみ記述する.

1 時点ではノードの分割の要素を除けば，状態 (富) と投資比率が一意に対応している．た だし，線形近似 [-state] は積立比率が 1 を越える場合 (富 $W_{1}>458.1$ ) でも投資をしており， 投資比率を線形に固定したことの影響が出ている。混合型線形近似 [hybridstate] は $T-1$ 時点において，状態 (富) と投資比率が一意に対応していない. 混合型投資比率 [hybridratio] では富の分布が狭い範囲に集中するために投資比率が低くなり，結果として状態 (富) と投 資比率が一対一で対応することが多い.

特に $T-1$ 時点の投資比率は解析解よりも低い. $T-1$ 時点の解はリバランスが不可能, 

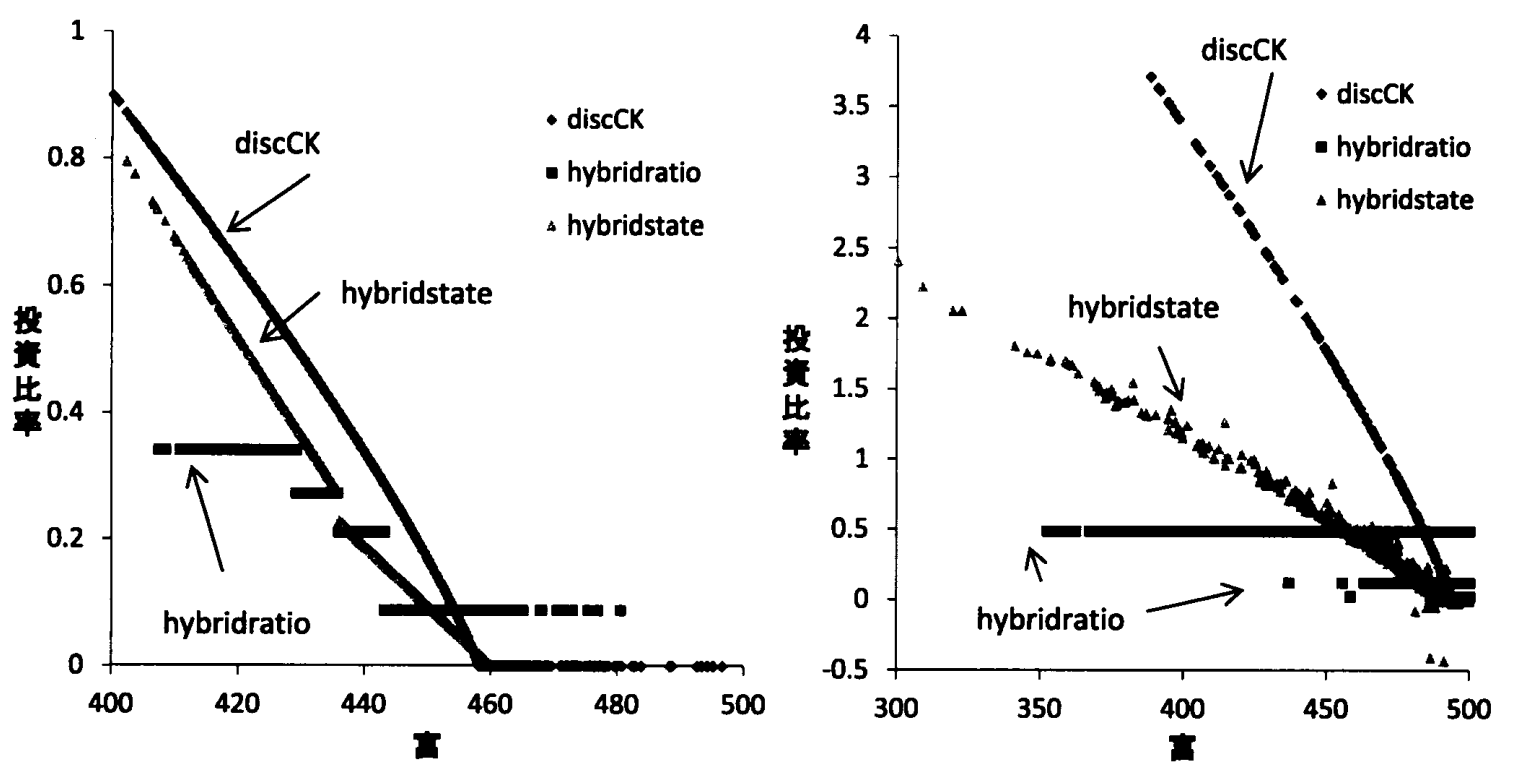

図 8: 1 時点 (左) と $T-1$ 時点 (右)の富と投資比率の関係

つまり将来の柔軟性がない状態の值であるため, その影響で解析解より低くなる。これは ノード数を増やすと投資比率が大きくなるのと同様であり, 最適ポートフォリオは将来の柔 軟性の影響を強く受けることを示している。

LPM $(1)$ における線形近似 [-state, piecewise] は状態 (富) と投資比率が一対一に対応しな い場合があり，富が基準值を超えても投資をすることになる．これは富が低いときや満期付 近で投資比率が極端に高くなり，比率近似アルゴリズムの計算を更新する度に富の值が大 きく変わることが原因であり，CRRA 型モデルとは異なる点である．これを回避するには, 投資比率を低くする (上限を設けるなど), 誤差の累積を回避する (リバランスの回数を減ら す)などといった工夫が必要である.

\subsection{2. ケース 2 : 連続時間の解との比較 $(\Delta t$ による違い)}

意思決定の時間間隔 $\Delta t$ を変化させた場合のリスク值と 0 時点投資比率を図 9 に示す.

時点分割数を増やして連続時間に近づけても，シミュレーション型投資比率 [Simratio] は ほとんど改善しない. 他のモデルは改善しているため, 状態に応じた意思決定が必要である と言える. 線形近似 [-state] の効果も時点分割数を増やすほど高い. 時点分割数が 2 のとき は線形近似なしでもほほ同じリスク値だが，増やすほどリスクが減る. 目的関数の改善効果 はリバランスの回数と将来の意思決定の柔軟性両方が影響しており, 片方だけでは効果がな いと言える。

\subsection{3. ケース 3：初期樌立比率に関する分析}

0.01 刻みで初期積立比率 $Y_{0}$ を変化させた場合のリスク值と 0 時点投資比率を図 10 に示す.

混合型投資比率 [hybridratio] に比べ，線形近似 [-state] はリスク值が低くなっている．問 題規模を考慮しても線形近似 [-state] の方が優れていることを数值的には示している。たた し，これらのリスク値の差はほとんどなく，連続時間の解析解 [CK] から大きく離れている こと, 初期積立比率が低い $\left(Y_{0}<0.7\right)$ 場合は解析解の割り当て $[\operatorname{discCK}]$ よりもリスク值が 大きくなることから，ノード分割を工夫することで解が改善する可能性が高い.

次に，0時点投資比率について述べる. 混合型線形近似 [hybridstate] の 0 時点投資比率は 


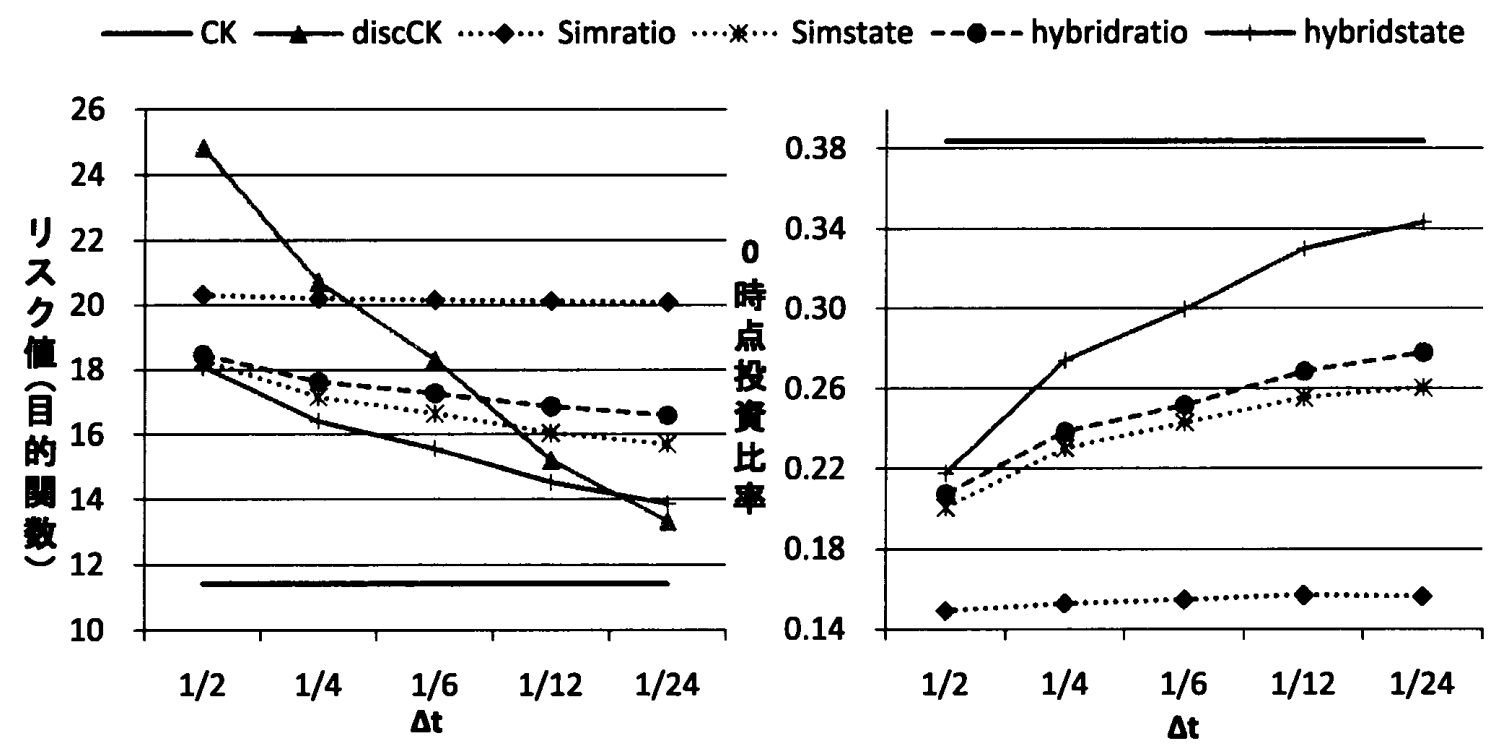

図 9: $\Delta t$ の違いによるリスク值 (左) と 0 時点投資比率 (右)
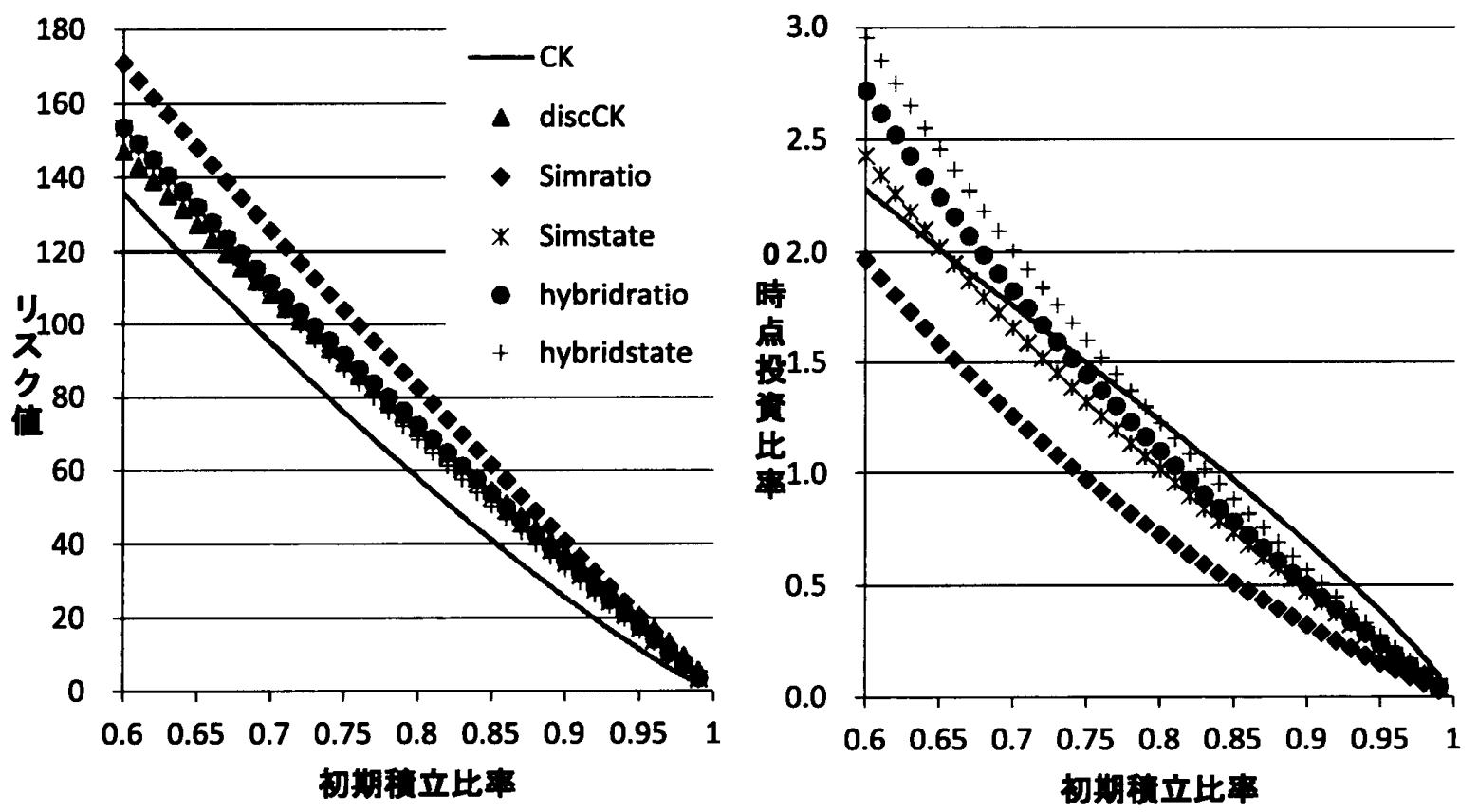

図 10: 初期積立比率の違いによるリスク值 (左) と 0 時点投資比率 (右)

他のモデルよりも高くなっており，モデルによって差が出ている．また，混合型投資比率 [hybridratio] もシミュレーション型線形近似 [Simstate] より投資比率が高く，ノード分割に よって投資比率が高くなることを示している．これは積立比率が低いほと顕著である。一方 で, 初期積立比率 $Y_{0}>0.8$ では解析解 $[\mathrm{CK}]$ が他のモデルよりも投資比率が高いなど, 解の 大小関係は一定ではない.

初期積立比率によって解析解との大小が異なる理由について述べる．LPM(1)の特性上, 初期積立比率が低い場合，投資比率を高くする方が良くなる．仮にいくら投資しても目標富 にいかない場合，すなわち極限では 1 次のモーメントを最大化する問題に書き変わるため, レバレッジに制約がなければ投資比率は無限に増える．離散時間のリバランスの機会は連続 
時間よりも少なく，初期值が低ければ目標富に到達する可能性が低くなる，そのため，投資 比率を増やすことで到達する可能性を上げようとし，積立比率が低い場合にはより投資比 率が高くなる。一方，積立比率が高い場合には連続時間に比べて相対的に無リスク資産が 有効な資産になる．積立比率 0.99 の場合，今回のパラメータでは無リスク資産にのみ投資 し続けることで LPM(1) は 5 以下が保証される．最適化を割り当てた [discCK] では平均で 5 以上なので，リスク資産に投資しても自明によい解がない. そのため，無りスク資産への 投資が多くなる，連続時間における最適解 (解析解) は，期中の積立比率が 0 から 1 をとる ことを前提にした解であり，1を超えることはない。一方，離散時間では投資比率を高める と積立比率が 1 を超えるパスが出るとともに，リスク值 (目的関数) も悪化する.そのため, 初期積立比率が高いとリスクを取らないことが最適解になる．ある時点で積立比率が 1 以上 になると，将来の意思決定が柔軟な方が無䭾なリスクを取らない戦略を構築することが可能 であるため，0 時点の投資比率を高くしてもリスクを背負わないことが可能になる.

\section{3. 結論}

CRRA 型との違い 連続時間リバランスの影響が出やすく，連続時間最適解に対する投資 比率，目的関数值の差がともに大きい. 線形近似関数の導入の効果は CRRA ほど大き くない.また, $\Delta t$ の大きさによって線形近似関数の導入の効果が変わり，連続時間に 近い (時点分割数が大きい) 方が効果が高い. 逆にいえば，連続時間に近くなければ混 合型投資比率モデルをそのまま利用しても問題ないといえる.

線形近似関数の首入の効果 混合型ノード分割をするよりも目的関数の值は改善するが，意 思決定の回数が増えない限り限定的である.

投資比率 従来の混合型投資比率モデルと大きく異なり，解析解に比較的近い(高いレバレッ ジの) 投資をすることが増える．0時点投資比率はモデル，状態によって大きく異なる.

目的関数值の改善が限定的な理由は以下の通りである。より詳細に離散時間の解法を調べ る場合，下記の点も考慮する必要がある.

・混合型線形近似モデルの限界 (非線形な関数を線形近似する影響)

- 意思決定の回数が少ない(離散時間の限界)

- 混合型ノード分割の方法

・ 線形近似関数と組み合わせても収束しやすい比率近似アルゴリズムの計算方法

\section{6. まとめと今後の課題}

本論文では，混合型多期間最適化モデルにおける投資量関数を工夫する方法で解析解の特 徵を考慮した状態依存の最適な意思決定が可能であるモデルを提案し, 解析解やモンテカ ルロ回帰 (MCR) と解の比較を行った. CRRA 型においては MCR に比べて解析解に近い投 資比率を導出でき，目的関数の值も改善したことを確認した. モンテカルロ回帰はLPM(1) のように富の水準に依存する目的関数を解くことは困難であるため，確率計画モデルである 線形近似モデルの方がより広い範囲に適用可能であると言える，LPM(1)をリスク尺度にす る場合も線形近似モデルについての分析を行い, 従来の混合型モデルよりも有利であること を確認できた。ただし，本研究での考察がノード分割方法を変えた場合でも成り立つかどう かは今後の課題である.

本研究において解析解およびモンテカルロ回㷌の最適解を制約条件なしで確率計画モデ ルと比較している理由は同じ条件のもとで比較するためである．この条件は確率計画モデ 
ルにとって有利な比較の方法ではない. なぜならば，確率計画モデルを利用すれば資産数を 増やしたり，制約を入れる場合等でも柔軟に対応可能であるからである．それにもかかわら ず，結果をみるとほほ同じような投資比率を得ることができており，確率計画モデルを利用 することの有用性を確認することができたと言ってよいだろう．ただし，複雑な確率分布の 場合の状態変数の選定や投資比率が微分不可能になる点での適切なノード分割の方法，オー バーフィッティングはアウトサンプルや精度の高い準乱数を用いた場合でも起こるのかどう か, 解析解が求まらない現実的な状況においても線形関数による近似が他のモデルに比べて 優位になるかの比較は今後の課題である.

\section{参考文献}

[1] J.H. van Binsbergen and M.W. Brandt: Optimal asset allocation in asset liability management. NBER Working Paper, 12970 (2007).

[2] J.H. van Binsbergen and M.W. Brandt: Solving dynamic portfolio choice problems by recursing on optimized portfolio weights or on the value function?. Computational Economics, 29 (2009), 355-367.

[3] E. Bogentoft, H.E. Romeijn, and S. Uryasev: Asset/Liability management for pension funds using CVaR constraints. Journal of Risk Finance, 3 (2001), 57-71.

[4] M.W. Brandt, A. Goyal, P. Santa-Clara, and J.R. Stroud: A simulation approach to dynamic portfolio choice with an application to learning about return predictability. Review of Financial Studies, 18 (2005), 831-875.

[5] G. Calafiore: Multi-period portfolio optimization with linear control policies. Automatica, 44 (2008), 2463-2473.

[6] B.R. Cobb and J.M. Charnes: Approximating free exercise boundaries for Americanstyle options using simulation and optimization. Proceedings of the 2004 Winter Simulation Conference (2004).

[7] J. Cvitanić and I. Karatzas: On dynamic measures of risk. Finance and Stochastics, 3 (1999), 451-482.

[8] J. Detemple, R. Garcia, and M. Rindisbacher: Simulation methods for optimal portfolios. In J.R. Birge and V. Linetsky (eds.): Handbooks in Operations Research and Management Science: Financial Engineering (Elsevier, North Holland, 2007), 867-924.

[9] L. Garlappi and G. Skoulakis: Numerical solutions to dynamic portfolio problems: The case for value function iteration using Taylor approximation. Computational Economics, 33 (2009), 193-207.

[10] 枇々木規雄: 戦略的資産配分問題に対する多期間確率計画モデル. Journal of the Operations Research Society of Japan, 44-2 (2001), 169-193.

[11] 枇々木規雄: 最適資産配分問題に対するシミュレーション/ツリー混合型多期間確率計 画モデル. 高橋一 (編): ジャフィー・ジャーナル 金融工学の新展開 (朝倉書店, 2001), $89-119$.

[12] 枇々木規雄: コンパクト表現によるシミュレーション型多期間確率計画モデルの定式化. Journal of the Operations Research Society of Japan, 45-4 (2002), 529-549. 
[13] 枇々木規雄: シミュレーション型多期間確率計画モデルに対する数値実験による考察. 日本金融・証券計量・工学学会 2002 年夏季大会予稿集, 81-100.

[14] N. Hibiki: Multi-period stochastic optimization models for dynamic asset allocation. Journal of Banking and Finance, 30 (2006), 365-390.

[15] M. Kawaguchi and N. Hibiki: Dynamic asset and liability management models for pension systems - The Comparison between multi-period stochastic programming model and stochastic control model - . The 13th Annual Conference of The Asia-Pacific Risk and Insurance Association (2009).

[16] T.S. Kim and E. Omberg: Dynamic nonmyopic portfolio behavior. The Review of Financial Studies, 9-1 (1996), 141-161.

[17] 梅内俊樹: 多期間最適ポートフォリオ問題—LSM 法を利用した近似解法の近似精度. 津 田博史, 中妻照雄, 山田雄二 (編): ジャフィー・ジャーナル 非流動性資産の価格付けと リアルオプション (朝倉書店, 2008), 184-212.

付録

\section{A. 計算速度}

モンテカルロ回帰および確率計画モデルにおける計算速度を比較する．パラメータはすべ て表 5 に示した標準パラメータとするが，混合型投資比率モデルのみノード数を 4 とする (hybridratio-4 と記述する). モンテカルロ回帰は表 2 に示した 4 通りも含めて示す. サンプ ルパスは事前に準備し，そのデータの読み込みから計算およびデータの保存の出力までの時 間を示す．モンテカルロ回帰の収束判定はアルゴリズムによって異なるが，0時点の投資比 率はほほ一致している．また，確率計画では，モデル，目的関数によって計算回数が異なる.

表 8: 計算速度比較

\begin{tabular}{ccrrc}
\hline 計算方法 & 計算アルゴリズム/モデル & CRRA & CRRA & LPM \\
サンプルパス数 & & 4000 & 10000 & 5000 \\
\hline \multirow{3}{*}{ モンテカルロ回㷌 } & BGSS & 3.29 秒 & 7.61 秒 & - \\
NMCR0] & 期待効用最大 & 16.03 秒 & 39.78 秒 & - \\
& 二乗值最小化 & 15.25 秒 & 38.59 秒 & - \\
\hline \multirow{2}{*}{ 確率計画 } & Simratio & 15.55 秒 & 47.19 秒 & 23.74 秒 \\
& hybridratio-4 & 17.28 秒 & 51.37 秒 & 26.13 秒 \\
& Simstate & 26.69 秒 & 80.82 秒 & 35.56 秒 \\
\hline
\end{tabular}

枇々木 規雄

慶應義塾大学 理工学部 管理工学科

厂 223-8522 横浜市港北区日吉 3-14-1

E-mail: hibiki@ae.keio.ac.jp 


\title{
ABSTRACT \\ DYNAMIC PORTFOLIO OPTIMIZATION USING MONTE CARLO SIMULATION
}

\author{
Keisuke Takaya \\ Norio Hibiki \\ Daiwa Securities Co. Ltd. Keio University
}

This paper discusses a stochastic programming approach for a multi-period portfolio optimization problem. Hibiki (2001) advocates the simulation/tree hybrid model for solving a multi-period optimal asset allocation problem with Monte Carlo simulation. We propose a linear approximation model based on the hybrid model, and compare it with other optimization models in the numerical examples, such as the stochastic programming models (i.e., the simulation model and the hybrid model), continuous-time models in which analytical solutions can be derived, and a Monte Carlo regression model proposed by Brandt et al. (2005). The results show better values can be derived in the linear approximation model than other models in the problems of CRRA utility function and the first-order lower partial moment which is one of the downside risk measure. In addition, the investment ratio at the initial time has got closer to the analytical solution. The objective function value of our model is improved in comparison with the hybrid model under the same scale problem. Especially in the CRRA case, the expected utility is larger and the investment ratio dependent of the state has become closer to the analytical solution than the Monte Carlo regression model. These results indicate that our model has the desirable properties for solving a multi-period portfolio optimization problem. 